1

\title{
The geochemistry and origin of the hydrothermal water erupted at Lusi, Indonesia
}

Adriano Mazzini ${ }^{1}$, Florian Scholz ${ }^{2}$, Henrik Svensen ${ }^{1}$, Christian Hensen ${ }^{2}$, Soffian Hadi $^{3}$

(1) CEED, University of Oslo, Oslo, Norway (adriano.mazzini@geo.uio.no)

(2) Geomar, Kiel, Germany

(3) BPLS, Surabaya, Indonesia

\section{Abstract}

The spectacular Lusi mud-eruption started in northeast Java on 29 May 2006. Despite extensive research, the origin of the erupted water remains elusive and poorly constrained. Here we present a comprehensive study of the geochemistry of Lusi waters compared with those collected from surrounding areas, all collected between 2006-2013, including data from mud volcanoes and volcano-hosted hydrothermal springs. Within this broad context, the geochemical characteristics of the fluids expelled in the Lusi region suggest that we can classify the waters in three groups: 1) meteoric waters expelled in cold springs and artesian wells, 2) hydrothermal waters typically mixed with meteoric waters, and 3) formation water from marine sediments altered by diagenetic processes such as clay-mineral dehydration. Samples collected from the Lusi crater are $\mathrm{Cl}$ and $\mathrm{Na}$ dominated (up to $527 \mathrm{mM}$ and 471.7 $\mathrm{mM}$, respectively) similar to seawater indicating that altered sedimentary formation waters are predominant in this system. In addition they are enriched in $\operatorname{Sr}$ (up to $808.4 \mu \mathrm{M}$ ) and other elements commonly associated with hydrothermal systems, such as $\mathrm{Li}$ (up to $877.6 \mu \mathrm{M}$ compared to $26 \mu \mathrm{M}$ in seawater). Some of these elements are up to ten times enriched 
compared to seawater values. High-temperature fluid mineral interactions in the subsurface appear to have facilitated the transfer of $\mathrm{Li}$ and other mobile elements into the fluids. High temperature fluid-mineral interaction reactions are also supported by $\mathrm{Si}$ concentrations significantly higher compared to other sampled mud volcanoes in the island. Crater samples also show the highest $\delta^{18} \mathrm{O}$ values ( $+5 \%$ after correction for evaporation compared to $+1 \%$ at the MV localities). ${ }^{87} \mathrm{Sr} /{ }^{86} \mathrm{Sr}$ ratios vary between of 0.7077 and 0.7083 and seem to reflect a general mixture of fluids from clay-mineral dehydration, carbonate recrystallization, alteration of volcanic rocks and hydrothermal imprint. Eight years of geochemical monitoring indicate that the composition of the deep-sourced Lusi fluids remain fairly constant through time. Thus our findings show that the Lusi crater waters represent a regional geochemical anomaly, and we suggest that a combination of high temperatures in the source region, and fluid-rock interactions with silicates and, possibly, carbonate-rich lithologies can explain the data. This is consistent with a model where the emitted gases migrate from a deep-seated ( $>4$ $\mathrm{km}$ ) source region, likely associated with the presence of hot igneous intrusions and/or high T reactions related to the presence of neighbouring active volcanoes.

\section{Introduction}

Hydrothermal systems hosted by sedimentary basins are characterized by a range of processes that influence the geochemistry of the involved fluids. Leaching or dissolution of detrital minerals and interactions with organic matter and petroleum may lead to element enrichment (e.g., Li, B, N, Br, I). Increasing pressure and temperature with depth result in mineral dehydration processes that involve the release of structural water during the 
51 transformation into secondary minerals. These reactions include smectite-illite 52 transformation, opal dehydration, and deeper metamorphic dehydration reactions. The

illitization of clay minerals typically starts at temperatures around $60{ }^{\circ} \mathrm{C}$ and is nearly completed at $160{ }^{\circ} \mathrm{C}$. The final result is freshened pore waters with a signature revealing increased $\delta^{18} \mathrm{O}$ values and decreased $\delta \mathrm{D}$ (Dählmann and de Lange, 2003). The depths at which these reactions occur depend on the local geothermal gradient, therefore in low gradient sedimentary basins these reactions occur at several kilometres depth, while in sedimentary basins close e.g. to volcanic systems most processes are shifted towards shallower depths. (Shanks et al., 1995; Sheppard and Gilg, 1996; Dählmann and de Lange, 2003). Thus in these systems there is a continuous and progressive alteration of the original pore water composition throughout the diagenetic and burial cycle. Depending on the complexities of the geological setting, the affected waters will migrate towards the surface and mix with low temperature pore fluids on the way (e.g. Haese et al., 2006; Hensen et al., 2007, and authors referred therein). For example meteoric water input result in a shift $\delta^{18} \mathrm{O}$ and $\delta \mathrm{D}$ towards the meteoric water line (Craig, 1961). Other mechanisms that may alter the original fluids composition once they reach the surface include the effect of evaporation. As lighter isotopes evaporate more efficiently, the remaining pore fluids become gradually enriched in both the heavy $\mathrm{O}$ and D isotopes (Gibson et al., 2008). These processes are described from well-characterized active sediment-hosted hydrothermal systems (SHHS) such as the Salton Sea geothermal system, the Guaymas Basin rift zone in the Pacific, the aligned eruptions in central Java, the Tiber-Delta gas system near Rome, and the areas with large igneous intrusions such as in the Northeast Atlantic, in South Africa and Australia (Simoneit, 1985; Vondamm et al., 1985; Welhan and Lupton, 1987; Jamtveit et al., 2004; Svensen et al., 2007; Mazzini et al., 2011; Holford et al., 2013; Mazzini et al., 2014; Ciotoli et al., 2016; Mazzini and Etiope, 2017). An important lesson from these studies is that even 
relatively small igneous intrusions in sedimentary basins may drive hydrothermal convection and alteration on timescales of $>10,000$ years.

The Indonesian Lusi eruption (Mazzini et al., 2007), ongoing since 2006 represents one of the most impressive active geological phenomena present on Earth that has been studied since its birth. Here a massive amount of boiling mud breccia and water are continuously spewed out from two large venting sites (up to $100 \mathrm{~m}$ wide the largest) and from numerous satellite seeps. Flow rates reached up to $180,000 \mathrm{~m}^{3} /$ day covering a surface of $\sim 7$ $\mathrm{km}^{2}$. This vast area is framed by a $10 \mathrm{~m}$ tall embankment that protects the surrounding settlements. Inside the embankment the walkable dry mud breccia allows to approach the crater up to $\sim 200 \mathrm{~m}$ and to sample fluids from seeps and from the high temperature streams that radially flush the erupted solid and the fluid phases. Based on these observations and on the intermittent eruptive behaviour that characterized Lusi since its birth, Mazzini et al. (2007) initially defined Lusi as a "quasi hydrothermal system". Extensive gas analyses showed that $\mathrm{CH}_{4}, \mathrm{CO}_{2}$ and $\mathrm{He}$ data (the latter with $\mathrm{R} / \mathrm{Ra}$ up to 6.5) are consistent with a deep origin linked to hydrothermal fluids that interact with igneous intrusions associated with the neighbouring ( 10 km, see Fig. 1) Arjuno-Welirang (AW) volcanic complex (Mazzini et al., 2012). Lusi represents indeed a new example of a hydrocarbon-rich sedimentary basin whose progressive natural diagenetic evolution has been perturbed by anomalous external factors (i.e. high geothermal gradient, volcanic processes). However a key difference between Lusi and for example the active sediment-hosted systems in California and Mexico is the focussed fluid flow and the high rates of erupted volumes. Even though Lusi is often described as a mud volcano (MV) in the literature, it does not share the key characteristics of the sedimentary volcanism such as a $\mathrm{CH}_{4}$-dominated gas composition, a short eruption period, and waters typical of basinal brines (cf. Mazzini et al., 2007; Etiope and Martinelli, 2009; Etiope, 2015). A more detailed description and distinction between the definition of purely 
sedimentary systems (i.e. sedimentary volcanism driven by gravitative instability and fluids overpressure generated in hydrocarbon prone settings) and hybrid systems (i.e SHHS, where magmatic or hydrothermal $\mathrm{CO}_{2}$-rich and vapour-rich fluids, related to igneous intrusions and high temperature geothermal fluids, cross organic-rich and $\mathrm{CH}_{4}$-rich sedimentary rocks) is provided in Mazzini and Etiope (2017). In addition the geysering behaviour that characterizes Lusi since 2006, makes it a unique example of a clastic-dominated geysering system (Karyono et al., 2016). In summary, Lusi shares many of the typical features of both hydrothermal systems and MVs, but these analogies fail to give insight into the origin of Lusi and the processes at work.

Sampling conducted during the early stages of the eruption showed the presence of mud and water originating from illitized clays between 1500-1800 m depth, however, deeper sources were not excluded (Mazzini et al., 2007; Istadi et al., 2009; Sawolo et al., 2009). This "deeper scenario" hypothesis is indeed supported by the gas composition that indicates sources and temperatures from depths greater than $4 \mathrm{~km}$. In order to study the sources of the erupted fluids we conducted an intense sampling campaign since the beginning of the eruption.

Here we present the first detailed characterization of the waters in the Lusi crater and compare the data with relevant waters from the same region. Our dataset of eight years of sampling aims at presenting a new frame of reference for interpreting the Lusi system and to provide a new understanding of the origin of the erupted waters.

\section{Geological setting}

Lusi is located in the backarc basin of North East Java in the immediate vicinity of the Arjuno-Welirang volcanic complex. The backarc basin has been characterized by an 
extensional regime and numerous faults. The Watukosek fault system originates from the AW volcanic complex and extends towards the NE of Java with numerous strike-slips faults (Istadi et al., 2009; Moscariello et al., this issue; Sciarra et al., this volume). This fault system, hosting Lusi and a number of MVs towards the NE (Kalang Anyar, Gunung Anyar, and Pulungan MVs) is interpreted to be the pathway for deep fluids migrating towards the surface feeding Lusi and the other structures (Mazzini et al., 2009; Mazzini et al., 2012). The basin is characterized by very high sedimentation rates resulting in the deposition of 1) shallow alluvial sediments $(0-290 \mathrm{~m})$; 2) Pleistocene alternating sandstone and shale of the Pucangan Formation, (up to $900 \mathrm{~m}$ depth), 3) Pleistocene bluish gray clay of the Upper Kalibeng Formation (up to $1871 \mathrm{~m}$ ) 4) Plio-Pleistocene volcaniclastics (at least $962 \mathrm{~m}$ thick); Oligocene-Miocene carbonates part of the Kujung sequence including Prupuh and Tuban limestones (up to $\sim 3.5 \mathrm{~km}(?)$ ), and 5) Eocene organic-rich shale source rock of the Ngimbang Fm. (after Mazzini et al., 2012 Fig. 6). Both the Upper Kalibeng and Ngimbang formations are organic-rich and capable of producing hydrocarbon-rich fluids.

It is important to stress that MVs and, in a broader sense, basin piercement structures 140 are typically present in basins with high sedimentation rate and rapid burial (e.g. Black Sea 141 and Caspian Sea basins) (e.g. Ivanov et al., 1996; Planke et al., 2003). Key factors for the 142 formation of MVs are high pore pressures due to high sedimentation rates and low 143 permeability gravitationally unstable mud sequences, as well as mineral dehydration, and 144 generation of hydrocarbons due to thermal maturation of organic matter. Piercement 145 structures in general are indeed a common phenomenon in NE Java (Mazzini et al., 2007; 146 Satyana, 2008; Istadi et al., 2009; Mazzini et al., 2009; Istadi et al., 2012) in particular in the 147 region affected by the Watukosek fault system. Seismic images from this region also reveal 148 numerous buried palaeo-piercement structures (Istadi et al., 2012) even in the vicinity of the 149 AW volcanic complex. For example Istadi et al. (2009) described the presence of the Porong 
piercement that is interpreted to be a paleo collapse of an ancient hydrothermal system now imaged with seismic reflection data. This piece of evidence highlights that the propagation of fluids from the AW volcanic complex towards the NE, was already ongoing in the geological past. The future occurrence of similar structures towards the NE of Java would be consistent with the geological observations collected so far.

\section{Methods}

Detailed fieldwork in the period 2006-2013 targeted sampling of water from the Lusi 
micromoles per litre $(\mu \mathrm{M})$ (Table 1A-B). Accuracy and precision were monitored by measuring the IAPSO salinity standard on a regular basis (Gieskes et al., 1991). The concentrations measured for IAPSO were generally within $5 \%$ of seawater values at the salinity given on the IAPSO standard bottle and the accuracy was found to be $<2 \%$ relative standard deviation for all elements.

Isotope analyses were done at the Institute for Energy and Technology (IFE, Norway) and at the Helmholtz Centre for Environmental Research - UFZ (Germany). For oxygen isotopic analyses, $\mathrm{H}_{2} \mathrm{O}$ was equilibrated with $\mathrm{CO}_{2}$ at $25{ }^{\circ} \mathrm{C}$ for 24 hours. The $\delta^{18} \mathrm{O}$ composition of $\mathrm{CO}_{2}$ will then reflect the isotope composition of the original water sample. The impurities were separated from $\mathrm{CO}_{2}$ on a Poraplot GC column before on-line determination of $\delta^{18} \mathrm{O}$ using a Finnigan DeltaXP isotope mass spectrometer at IFE. The average value for GISP from IAEA is $\delta^{18} \mathrm{O}$ vSMOw $=-24.80 \pm 0.10 \%$ (one standard deviation). Certified value is $-24.78 \pm 0.08 \%$. Before measuring the $\delta \mathrm{D}$ composition $\mathrm{H}_{2} \mathrm{O}$ was reduced with $\mathrm{Zn}$ to $\mathrm{H}_{2}$ and $\mathrm{ZnO}$ in sealed, evacuated quartz vessels at $900{ }^{\circ} \mathrm{C}$. The $\delta \mathrm{D}$ composition was then determined by dual inlet, using a Micromass Optima isotope mass spectrometer. Average value for GISP from IAEA is $\delta \mathrm{D}$ vsmow $=-189.71 \pm 0.89 \%$ o $(1$ sigma). Certified value is $-189.73 \pm 0.90 \%$. $\delta \mathrm{D}$ and $\delta^{18} \mathrm{O}$ analyses were carried out at UFZ using a High-Temperature Pyrolysis (HTP) system coupled with an Isotope Ratio Mass Spectrometer (IRMS, Delta S, Finnigan MAT) (Gehre and Strauch, 2003). The results are reported relative to $\mathrm{V}-\mathrm{SMOW}$ with a precision $(2 \sigma)$ of $\pm 1.5 \%$ for $\delta \mathrm{D}$ and $\pm 0.4 \%$ for $\delta^{18} \mathrm{O}$.

Nine water samples from Lusi and other relevant stations were selected for ${ }^{87} \mathrm{Sr} /{ }^{86} \mathrm{Sr}$ isotopic analyses. Moreover, eight rock samples were selected for digestion, bulk geochemical and ${ }^{87} \mathrm{Sr} /{ }^{86} \mathrm{Sr}$ analysis (Table 2). These samples include: two samples of outcropping volcanic rocks from the neighbouring volcanic complex, two mud breccia shale 
samples collected inside the Lusi crater zone and three side well cores from the BJP1 well respectively at 3640ft $(1109 \mathrm{~m}), 4800 \mathrm{ft}(1463 \mathrm{~m})$, and 5200ft $(1585 \mathrm{~m})$ depth. BJP1well was a wildcat drilling located $\sim 200 \mathrm{~m}$ away from the ongoing Lusi eruption site (see more about BJP1 in Mazzini et al., 2007). Rock samples were dried, ground, and digested in an acid cocktail consisting of $\mathrm{HNO}_{3}, \mathrm{HClO}_{4}$ and $\mathrm{HF}$. The digestion solution were analysed at GEOMAR by ICP-OES. Certified reference materials were digested and analysed along with samples for quality control.

For further details on all chemical analysis carried out at GEOMAR refer to the following $\quad$ webpage: $\quad$ http://www.geomar.de/en/research/fb2/fb2-mg/benthicbiogeochemistry/mg-analytik/.

Strontium isotope ratios were determined at GEOMAR by Thermal Ionization Mass

\section{Results}

Table 1A-B and 2 summarise the elemental and isotopic composition of the sampled waters and the digested rocks. In order to systemize and present the data, we have subdivided the waters in four main groups according to the geological setting in which they were collected: 1) the Lusi crater, 2) satellite seeps surrounding the main crater, 3) MVs along the Watukosek fault system (Pulungan and Kalang Anyar at the intersection with the Pulungan anticline, and Gunung Anyar at the intersection with the Guyangan anticline), the Madura 
Island (Gunung Bulag, Genung Sening), and along the central Kedungwaru anticline (Pangangsong), and 4) hydrothermal springs in the AW volcanic complex (Pacet, Cangar, Songgoriti, Kepulungan) and sediment-hosted hydrothermal systems (here called "hot seeps" in the legends for simplicity) in central Java (Krewek, Bledug Kuwu; Mazzini et al., 2014). In addition, we present analyses of various surface waters, including fresh springs on the flanks of AW complex, rain water and water from artesian wells, and the Porong River upstream from the drainage outlet for the Lusi mud (Fig. 1 and Fig. 2).

\subsection{Overall characteristics}

Compared to the other samples from the collection, Lusi waters reveal a defined signature that generally clusters them in a distinct group. Lusi is enriched in most elements, with $\mathrm{Ca}$ up to $22.5 \mathrm{mM}$, Li up to $877.6 \mu \mathrm{M}$ and $\mathrm{Sr}$ up to $808.4 \mu \mathrm{M}$ (nearly 10 times seawater). Their composition is dominated by $\mathrm{Na}$ and $\mathrm{Cl}$ with concentrations that largely cluster between 339.8-471.7 $\mathrm{mM}$ and 399.2-527 $\mathrm{mM}$, respectively with $\mathrm{Cl}$ concentration slightly lower than that of sea water $(560 \mathrm{mM}$ at a salinity of 35$)$. Waters from the Javanese MVs reveal generally low $\mathrm{Ca}$ (below $2.5 \mathrm{mM}$ ) and $\mathrm{Cl}$ concentrations grouped between 347$756 \mathrm{mM}$ and between 91-113 for the Madura MVs. Waters collected from the Prong River, from artesian wells around Lusi and from cold springs in the volcanic arc, reveal low concentrations of most of the elements. Similarly the hydrothermal springs have low concentrations of most of the elements expect for $\mathrm{Si}$ and $\mathrm{Li}$.

The highest temperatures reported here, were measured around the boiling Lusi crater, giving temperatures from $87.5^{\circ}$ to $94.0^{\circ} \mathrm{C}$. Intermediate temperatures were found in the 
2

hydrothermal springs $\left(39.8^{\circ}-54.0^{\circ} \mathrm{C}\right)$ whereas most other waters were sampled at below $45^{\circ}$ C.

\subsection{Oxygen and hydrogen isotopes}

The $\mathrm{O}$ and $\mathrm{D}$ isotopes show that the Lusi crater values form a distinct cluster ranging between $7.8 \%_{0}<\delta^{18} \mathrm{O}<9.9 \%$ and $-12.6 \%<<\delta \mathrm{D}<0.1 \%$ (Fig. 3). They plot subparallel to the global meteoric water line (GMWL) and, in contrast with other localities, they have the highest $\delta^{18} \mathrm{O}$ values with enrichments by at least $10 \%$ compared to the rain water sampled in 2012. The samples collected from the hydrothermal springs around the flanks of the AW volcanic complex plot along the GMWL (except for one sample) similarly to the other surface water samples. Most of the MVs plot along the smectite to illite conversion line.

Fig. 4 shows the $\mathrm{Cl}-\delta^{18} \mathrm{O}$ relationship for the Lusi crater samples, revealing that the high $\mathrm{Cl}$ Lusi waters are most enriched in ${ }^{18} \mathrm{O}$. Fig. 5 shows $\mathrm{Li} / \mathrm{Cl}$ concentrations plotted against $\delta^{18} \mathrm{O}$ and reveals an apparent trend in increasing $\mathrm{Li}$ and $\delta^{18} \mathrm{O}$ for $\delta^{18} \mathrm{O}$ values above 2 permil. As also described for $\mathrm{Cl}-\delta^{18} \mathrm{O}$ plot, there is a near linear relationship between $\mathrm{Li}$ and $\delta^{18} \mathrm{O}$. Three groups can be defined: 1 -samples with low $\mathrm{Li} / \mathrm{Cl}$ values that include the shallow water localities (artisan wells, Porong River and some of the Lusi satellite seeps) as well as some MV sites; 2-samples showing a gradually increasing input of $\mathrm{Li} / \mathrm{Cl}$ and higher $\delta^{18} \mathrm{O}$. 261 This is typical for all the sampled MVs. 3- Lusi samples indicate combined increase of Li/Cl 262 and $\delta^{18} \mathrm{O}$. The hot seep and the hydrothermal springs have the highest $\mathrm{Li} / \mathrm{Cl}$ values and do not 263 follow the trend of the other samples. 


\subsection{Strontium Isotopes}

The Lusi crater water has Sr concentrations between 412 and $808 \mu \mathrm{M}$ similarly to the waters of same of the MVs and the satellite Lusi seeps. The highest $\mathrm{Sr}$ value has been measured at Bledug Kuwu (JV08-11) reaching nearly $1000 \mu \mathrm{M}$. Lusi samples selected for strontium isotope analyses show ${ }^{87} \mathrm{Sr} /{ }^{86} \mathrm{Sr}$ between of 0.7077 and 0.7083 (Table 1). These samples are less radiogenic than seawater $\left({ }^{87} \mathrm{Sr} /{ }^{86} \mathrm{Sr}=0.7092\right)$. A water sample from the Cangar locality fresh spring in the volcanic complex shows an isotopic ratio ${ }^{87} \mathrm{Sr} /{ }^{86} \mathrm{Sr}=$ 0.7131 (sample JV07-12) which is higher than the value from the hydrothermal Sanggoriti locality (sample JV11-08) that has ${ }^{87} \mathrm{Sr} /{ }^{86} \mathrm{Sr}=0.7088$. The Bledug Kuwu hot seep in central Java has ${ }^{87} \mathrm{Sr} /{ }^{86} \mathrm{Sr}=0.7078$, while the other MVs analysed gave rations between 0.7077 and 0.7109 .

The Sr isotope composition of the solutions obtained from the digestion of the solid phase (Table 2) allow for an estimate of the different $\mathrm{Sr}$ sources. The sediment samples from the BJP1 side well cores have ${ }^{87} \mathrm{Sr} /{ }^{86} \mathrm{Sr}$ ratios greater than seawater (between 0.7101 and 0.7114) and their values are increasing consistently with depth. The samples from the volcanic rocks show, as expected, lower values $(0.7044)$, while the mud breccia black shales give ratios of 0.7088 .

\subsection{Time series}

Fig. 6 shows a compilation of Lusi crater data plotted against sampling year. $\delta^{18} \mathrm{O}$ and $285 \delta \mathrm{D}$ reveal synchronous variations through time with a partial $(\sim 1.5 \%)$ decrease after 2006 286 and a gradual increase after 2008. Fig. 6 shows that $\mathrm{Li} / \mathrm{B}$ and $\mathrm{I} / \mathrm{Br}$ are fairly constant over 
time (ranging between $0.06-0.15$ for $\mathrm{Li} / \mathrm{B}$ and between $0.13-0.17$ for $\mathrm{I} / \mathrm{Br}$ ). Other elements also show nearly constant values throughout the monitoring period.

\subsection{Iodine and Bromine}

Iodine and Bromine values reveal clear clustering trends (Fig. 7). Localities and samples that have strong meteoric component show very low values for both iodine and bromine. These are the Porong River, the hydrothermal springs, and some of the Lusi satellite seeps. A trend line connects this first group with the Lusi samples that form a defined cluster. Along this trend line fall the MVs with stronger meteoric input. A second trend line includes the other sampled MVs with gradually increasing iodine and bromine.

\section{Discussion}

\subsection{Clay mineral dehydration}

Clay mineral dehydration is a widespread process occurring at elevated temperatures and pressures within terrigeneous sedimentary deposits. Clay mineral analyses of side well cores from the BJP1 borehole (located nearby Lusi) revealed that smectite-illite transformation is present at least between 1109 to $1828 \mathrm{~m}$ (Mazzini et al., 2007). These results show that the dehydration progress increases exponentially with depth, being almost completed at 1828 and already ongoing at the depth of $1109 \mathrm{~m}$ and probably even shallower. Lusi water analyses presented here confirm these findings and suggest that a significant part of the fluids originate from clay mineral dehydration. In general, the fluids expelled at Lusi originate from buried marine deposits (including the formation waters of the Kalibeng Fm. and probably also from 
the deep-seated Ngimbang Fm), which are characterised by seawater $\mathrm{Na}$ and $\mathrm{Cl}$ concentrations. However, Lusi $\mathrm{Na}$ and $\mathrm{Cl}$ concentrations are lower than seawater in all samples (see Tab. 1) and, moreover, are highly enriched in Li and B (Table 1, Fig. 5) and show a typical trend of higher $\delta^{18} \mathrm{O}$ and lower $\delta \mathrm{D}$ values with respect to SMOW (Fig. 3). This has been observed in various MV settings (e.g. Dählmann and de Lange, 2003; Scholz et al., 2010a; Hensen et al., 2015). Based on these observations, meteoric water input as a main source of freshening can be ruled out at Lusi.

\section{2. Lusi water signature evolution: evaporation effect and meteoric fluids}

A key goal to our geochemical monitoring was to distinguish the deep and shallow geochemical signals mixing at the Lusi site. In Figure 6A, we show element ratios of typical inorganic $(\mathrm{Li} / \mathrm{B})$ and organic $(\mathrm{I} / \mathrm{Br})$ fluid tracers, which are released during diagenetic reactions at depth, in a time-series plot over a time span of 8 years. The $\mathrm{Li} / \mathrm{B}-\mathrm{I} / \mathrm{Br}$ time-series show that the values remain fairly constant over time. Given the slow reaction progress of most geochemical processes that take place in the subsurface at deep- sourced systems, we conclude that the fluid erupted at Lusi has a relatively constant composition over time.

In contrast, Lusi $\delta^{18} \mathrm{O}$ and $\delta \mathrm{D}$ time-series (Fig. 6B) show that there are some temporal variations, while changes in $\delta^{18} \mathrm{O}$ and $\delta \mathrm{D}$ are constantly positively correlated (n.b.: dehydration generates a negative correlation; Fig. 3). Since changes in the deep source composition can likely be ruled out (Fig. 6A), this observation suggests that external "shallow" factors are responsible for the observed isotopic variations with time. There are two main candidates that may affect the fluid signature: admixing of meteoric fluids and evaporation. 
Indeed one factor that may alter the original fluid composition is the amount of meteoric fluids entering in the system. Raining events occurring in the period prior to the sampling may alter the fluid signature and cause the relatively small shifts described herein.

An alternative, or combined, scenario is the effect of evaporation. Unfortunately, the amount of water lost from the Lusi crater due to evaporation is difficult to quantify and remains poorly constrained. Evaporation is likely connected with the crater activity, which is characterized by intermittent and violent geysering discharge phases resulting in tall vapour plumes. Overall, the flow rate and the aqueous vapour discharge were higher in 2006, which could explain the higher oxygen and deuterium isotope data recorded during the initial phases of the eruption (cf. Fig. 3). Supporting evidence favouring evaporation as a combined process is provided by comparing the $\mathrm{Cl}$ and $\delta^{18} \mathrm{O}$ values (Fig. 4). Fluids from most of the other MVs and those from Lusi are characterized by similar $\mathrm{Cl}$ concentrations. In contrast $\delta^{18} \mathrm{O}$ is significantly higher at Lusi, indicating a stronger impact from illitization. Hence, $\delta \mathrm{O}-\delta \mathrm{D}$ values from Lusi samples should theoretically plot along the illitization line (grey-shaded circle in Fig. 3). The observed positive offset in both parameters can be best explained by evaporation, as all samples are approximately aligned along the expected evaporation trend line. Similar conclusions may be obtained from Fig. 4 that shows evidence of the evaporation effect after the contribution of fluids from illitized clays.

Fig. 3 indicates that sea water and clay mineral-derived water are prominent components in most of the samples collected from Lusi (except for few satellite seeps). We stress that these waters do not contain major components of meteoric water. The sea water to mineral-derived water ratio can be estimated using end member $\delta \mathrm{D}$ and $\delta^{18} \mathrm{O}$ values, see for instance Dählmann and deLange (2003) using values of -70 and 20 for $\delta \mathrm{D}$ and $\delta^{18} \mathrm{O}$, respectively. Considering that seawater has $\delta \mathrm{D}$ and $\delta^{18} \mathrm{O}$ of zero and that the Lusi samples 
prior to evaporation (grey-shaded circle in Fig. 3) have a $\delta \mathrm{D}$ of -19 and $\delta^{18} \mathrm{O}$ of 6 , the resulting mixing ratio is 0.7 (i.e. a $70 \%$ seawater fraction).

Mazzini et al. $(2007 ; 2009 ; 2012)$ reported that Lusi and the Watukosek fault system responded to seismic activity in numerous instances (e.g. with sudden increase in flow rate, and fractured dam walls). However, so far it has not been investigated if sudden changes in chemistry occurred during these specific events. A denser sampling rate is needed to investigate geochemical timeseries for this purpose.

\subsection{Meteoric fluid-dominated localities}

The presence of meteoric fluids is indicated by low concentrations of all elements analysed at certain locations. This is obvious in the samples collected from the Porong River, from the MVs in Madura (i.e. sampled after rain), from shallow boreholes and cold springs around the AW complex or close to Lusi. Several of the Lusi satellite seeps also reveal strong dilution with shallow meteoric fluids. These are essentially the samples that plot along the GMWL in Fig. 3 and the one with low $\mathrm{Cl}$ values in Fig. 4. The samples collected from the hydrothermal vents on the AW volcanic complex reveal no signature of fluids originating from sea water, nor from illitization of clay minerals. The data show that at these hydrothermal vents the main source of fluids is meteoric with hydrothermal modifications as suggested by the strong enrichment in e.g. Li (Fig. 5) (James et al., 1999; You and Gieskes, 2001; Scholz et al., 2010a).

5.4. Interactions with carbonates, high temperature reactions, silicate minerals and organic matter 
The partial $\mathrm{Sr}$ enrichment observed in the Lusi water samples may be ascribed to

leaching from the carbonates of the Miocene Prupuh or Tuban and Oligocene Kujung Formations (e.g. Richter and Depaolo, 1988). The fact that the Lusi plumbing system intersects these carbonate formations is supported by the dating of scleractinian coral fragments as well as carbonate clasts consisting of planktonic foraminifera bearing mudstone.

These specimens have been found in the erupted Lusi mud breccia since the early stages in 2006 (Samankassou et al., this volume).

In addition all the Lusi waters are strongly enriched in $\mathrm{Li}, \mathrm{B}$, and $\mathrm{Ca}$ compared to the MVs in the area (Table 1). Previous gas analyses comparing the same set of piercement structures in NE Java (including Lusi) revealed a clear signature of mantle gas at Lusi (Mazzini et al., 2012). The exceptionally high concentrations of fluid mobile elements such as $\mathrm{Li}$ and $\mathrm{B}$ are consistent with this previous finding and could indicate that the fluids from clay dehydration are mixed with hydrothermal solutions that have interacted with basement rocks and overlying sediments/shales.at high temperatures

The only structures that appear to share water characteristics similar to Lusi are Bledug Kuwu and Krewek. The samples from Bledug Kuwu (JV08-11), Krewek (JV08-12) and the hydrothermal spring at Songgoriti (JV11-07) show extremely high $\mathrm{Li} / \mathrm{Cl}$ (and to a lesser extent also $\mathrm{B} / \mathrm{Cl}$ ) indicating that hydrothermal processes play a more important role than clay mineral dehydration or diagenetic processes in general (Table 1, Fig. 5). Lusi features $\mathrm{Li} / \mathrm{Cl}$ intermediate between the other MVs and hydrothermal springs and hot seeps which lends further support to our hypothesis that an additional hydrothermal Li source has to be invoked.

Interesting insights regarding the correlation between organic matter diagenesis and high-temperature reactions are provided by the variations of $\mathrm{I}, \mathrm{Br}$ and Li. Iodide and bromide 
are typical tracers for organic matter diagenesis in sediments and rocks (Martin et al., 1993; Gieskes and Mahn, 2007; Scholz et al., 2010b; Scholz et al., 2013). Hence the increase of I and $\mathrm{Br}$ indicates increasing intensity of organic matter decomposition. Often the increase in iodine and bromine and the proxies for clay dehydration coincide (Scholz et al., 2010b). The analysed dataset reveals two trends (Fig. 7). The first is a mixing trend between Lusi and meteoric water that is a simple dilution trend where Madura MVs and hydrothermal springs are strongly diluted. The second trend corresponds to an increasing intensity of organic matter decomposition. This trend appears to increase for the MVs to the NE of Lusi and described herein have higher iodide concentration than Lusi (Fig. 7). Considering that organic-rich formations feeding the MVs are the same throughout the NE of Java, one would expect similar values. Instead, lower I and the anomalously high $\mathrm{Li}$ enrichment observed in most of the Lusi samples (implying a decoupling of I and Li compared to the MVs) supports the idea that some of the Li-rich fluids originate not only from illitization but are also related to hydrothermal processes. High Li content is usually indicative of high temperature reactions at hydrothermal vents (James et al., 1999; You and Gieskes, 2001; Scholz et al., 2010a). We conclude that in the Lusi case there is an additional component of high-T processes involving low igneous or volcanic rocks (i.e. volcanoclastics unit below the bluish grey shales or altered igneous intrusions) compared to other MVs where organic-rich sediment-hosted processes are more prominent.

\subsection{Insights and implications from strontium signatures}

$\mathrm{Sr}$ isotopes are a powerful tool to distinguish the origin of the fluids (Anschutz et al., 1995; Scholz et al., 2009; Hensen et al., 2015). As the Sr concentrations in the meteoric water are low, a strong "meteoric" influence altering the ${ }^{87} \mathrm{Sr} /{ }^{86} \mathrm{Sr}$ ratios is rather unlikely. 
Therefore the isotopic values can be safely considered as good indicators for the origin of the waters despite any shallow fluid contamination.

Fig. 8 summarizes the $\mathrm{Sr}$ analyses completed both on the digested rocks and the sampled fluids defining the fields for different lithotypes and pinning the analysed specimens. The higher radiogenic values obtained for the bluish grey shale samples from the Kalibeng Fm. are consistent with those of fluids analysed from Gunung Anyar MV. This suggests that at least in this part of the island, the plumbing system of MVs is shallower than the Lusi one and does not extend below the Kalibeng Fm. Less radiogenic values are measured from the samples from the Ngimbang Fm as well as for the carbonate which age is constrained between late Oligocene-Miocene (Samankassou et al., this volume). Formation waters of carbonate rocks are known to become enriched in Sr during diagenesis (e.g. Gieskes et al., 1986; Richter and Depaolo, 1988), with ${ }^{87} \mathrm{Sr} /{ }^{86} \mathrm{Sr}$ ratios reflecting the time of deposition. The Lusi samples collected in the vicinity of the crater, revealed similar ${ }^{87} \mathrm{Sr} /{ }^{86} \mathrm{Sr}$ ratios and $\mathrm{Sr} / \mathrm{Li}$ ratios that average between the shales and the carbonates. The plot also indicates that in order to obtain the signatures of the Lusi fluids it is required a mixing between the various formations that are pierced by the feeder conduit. This is also consistent with the conclusions obtained comparing the waters sampled from various localities in the region.

\subsection{Summary and implications}

There are several water sources that can be assigned as part of the Lusi system based on the published data, the known stratigraphy and the data presented herein. These can be summarized as follow (Fig. 9).

1. Shallow meteoric fluids present in the recent alluvial sediments (intercalated sands and clay) less than $300 \mathrm{~m}$ deep. 
2. Formation water entrapped during the burial of marine sequences (e.g. the upper Kalibeng Fm. has sedimentation rates of about $2.5 \mathrm{~km} / \mathrm{Ma}$ since the Pleistocene).

3. Fluids originating from the illitization of the bluish grey clays of the upper Kalibeng Fm. (up to $1.8 \mathrm{~km}$ ) and the deeper sited (>3400 m) mudstones of the Ngimbang Fm.

4. Fluids originating from the carbonates of the Kujung-Propuh and Tuban Fms.

5. Lusi fluids have undergone hydrothermal exchange with deeply buried basement rocks of the neighbouring AW complex as well as the other formations mentioned above.

An important outcome of this study is the obvious need to emphasize the distinction between purely sedimentary systems (i.e. cold seeps and mud volcanoes), hybrid systems (i.e. sediment-hosted hydrothermal systems), and pure hydrothermal vents (i.e. systems entirely related to magmatic activity). Our results confirm that Lusi is not a mud volcano in the common sense but a sediment-hosted hydrothermal system and, as such, the erupted fluids shows contributions from sedimentary and hydrothermal origin. Our new data confirm the scenario depicted by Mazzini et al. $(2009 ; 2012)$ where hydrothermal fluids follow the strikeslip Watukosek fault system as a preferential pathway to move towards the surface. During their rise fluid compositions are altered by geochemical reactions that occur at various stratigraphic levels and range from low to high temperature. The final result is the cocktail still erupting at Lusi site.

\section{Conclusions}


Extensive monitoring conducted over eight years at the Lusi eruption site revealed a 3 4

fairly constant composition of erupted waters. Comparative analyses with other setting and structures in NE Java allowed classification of different components and interactions ongoing in the Lusi plumbing systems (Fig. 9).

- Lusi waters represent a geochemical anomaly with a remarkable enrichment in some elements especially when compared to other Javanese mud volcano that are hosted in the same basinal formations.

- A significant part of the fluids originates from clay mineral dehydration ongoing at the Kalibeng and Ngimbang Fms. This observation is provided by $\mathrm{Cl}$ and $\mathrm{Na}$ depletion compared to sea water as well as $\mathrm{Li}$ and $\mathrm{B}$ enrichments, higher $\delta^{18} \mathrm{O}$ and lower $\delta \mathrm{D}$ values with respect to SMOW.

- High $\mathrm{Li} / \mathrm{Cl}$ at Lusi suggests temperatures beyond typical diagenetic range and possibly injection of basement-derived fluids. This conclusion is supported by low $\mathrm{Br}$ and $\mathrm{I}$ concentrations (i.e. processes occurring within the basement with low organic matter content).

This unique collection of data provides a rare opportunity to observe the variations in geochemical composition of an ongoing eruption. It also highlights that the Lusi water plumbing system is much deeper than commonly thought. The Lusi eruption and the neighbouring volcanic complex are connected resulting in the rise of hydrothermal fluids that recycle the fractures of the Watukosek fault system as preferential pathways to migrate towards the surface.

\section{Acknowledgements}


This work was funded by the European Research Council under the European Union's

Seventh Framework Programme Grant agreement $n^{\circ} 308126$ (LUSI LAB project, PI A. Mazzini). We acknowledge the support from the Research Council of Norway through its Centers of Excellence funding scheme, Project Number 223272. The 7th Framework Program of the European Union supported the participation of FS (Marie Curie IOF \#300648, BICYCLE). BPLS is thanked for help and granting the access to Lusi site and to the numerous people for their help and fruitful discussions during the fieldworks. We also would like to acknowledge R. Surberg, A. Bleyer and B. Domeyer for performing geochemical analyses. We are grateful to the editor and two anonymous reviewers who provided valuable comments.

\section{Figure captions}

Fig. 1. Setting of the region and Lusi area. (A) Elevation map of eastern Java Island. Indicated are the positions of the studied mud volcanoes, hydrothermal vents localities, and the main anticlines (marked with A) as well as the Watukosek fault system intersecting Lusi and other MVs (white line). Note the alignment of the structures along the fault system. Symbols indicate the structures as indicated in the plots. Inset shows the Java Island with framed region magnified in the elevation map. (B) Measurements and sampling of Lusi water from one of the hot streams that radiate from the crater; Lusi hot plume in the background. (C) Panorama view of active Lusi crater from the outskirts. Arjuno Welirang volcanic complex in the background. 
519 Fig. 2. Satellite image around Lusi area on August 2014, courtesy of BPLS. Indicated the 520 sampling locations for samples classified as 1-Lusi Crater, 2-Lusi satellite seeps, 3-Porong 521 River. Note the embankment framing the mud-breccia-covered surface. The lighter grey area 522 is walkable and accessible dry mud breccia, unlike the darker area surrounding the active 523 crater that forms a large hydrothermal pond. From the edges of this pond the erupted water 524 funnels into hot streams (some arrowed in white) that extend radially flushing the fluids 525 towards the periphery.

527 Fig. 3. Plot of $\delta^{18} \mathrm{O}$ versus $\delta \mathrm{D}$. The black line is the Global Meteoric water Line (GMWL) 528 (Craig, 1961). The trend for smectite to illite conversion was taken from Dählmann et al. 529 (2003). The grey-shaded circle along the illitization trend line indicate the expected cluster of 530 Lusi samples in case normal illitization input (e.g. like for the other MVs).

532 Fig. 4. $\delta^{18} \mathrm{O}-\mathrm{Cl}$ relationship for the sampled waters. Supporting evidence of evaporation 533 process for Lusi samples is highlighted by increased $\delta^{18} \mathrm{O}$ values at similar levels of $\mathrm{Cl}$. 534 Arrows indicating the evaporation and the illitization trends are indicated. The Lusi non535 evaporated values are assumed to follow the illitization line and would plot over the indicated 536 grey shaded area.

538 Fig. 5. $\mathrm{Li} / \mathrm{Cl}$ versus $\delta^{18} \mathrm{O}$. $\mathrm{Li}$ s normalized to $\mathrm{Cl}$ to compensate for variable dilution with clay 539 mineral-derived or meteoric water. The samples strongly affected by meteoritic fluids show 540 low $\mathrm{Li} / \mathrm{Cl}$ values. There is a gradually increasing trend highlighting the presence of fluids 
541 coming from smectite-illite dehydration. This is typical for all the sampled MVs. Lusi

542 samples indicate combined illitized input and hydrothermal fluids as indicated by even higher

$543 \mathrm{Li} / \mathrm{Cl}$ and values $\delta^{18} \mathrm{O}$. The hot seep and the hydrothermal springs have the highest $\mathrm{Li} / \mathrm{Cl}$

544 values and do not follow the illitization trend.

546 Fig. 6. Comparative timeseries of the analysed Lusi samples since 2006. (A) $\mathrm{Li} / \mathrm{B}$ and $\mathrm{I} / \mathrm{Br}$ 547 indicate fairly constant values through time suggesting that the source of sediments did not 548 change significantly during the monitoring period. (B) Both $\delta \mathrm{D}$ and $\delta^{18} \mathrm{O}$ vary systematically. 549 These fluctuations are mainly ascribed to varying conditions of evaporation/crater plume 550 activity.

Fig. 7. Plot of iodide versus bromide. Black arrow depicts the inferred mixing and diagenetic 553 trends.

555 Fig. 8. Si/Li versus ${ }^{87} \mathrm{Sr} /{ }^{86} \mathrm{Sr}$ indicating the results of the dating and the molar ratios of the 556 analysed waters and the digested rocks of the various formations. A deeper and hotter source 557 is suggested for Lusi that receives the input of fluids from the illitized clays of the Kalibeng 558 Fm, the deeper sited Ngimbang Fm., the Oligocene and Miocene carbonates, and the high 559 temperature leaching from volcanic rocks. 
Fig. 9. Cartoon summarizing the various sources of water at the Lusi site. The traced sources

of gas are also indicated on a separate column (after Mazzini et al., 2012). Refer to section 2 for details about the stratigraphy.

\section{References}

Anschutz, P., Blanc, G., and Stille, P., 1995, Origin of Fluids and the Evolution of the Atlantis-li Deep Hydrothermal System, Red-Sea - Strontium Isotope Study: Geochimica Et Cosmochimica Acta, v. 59, p. 4799-4808.

Ciotoli, G., Etiope, G., Marra, F., Florindo, F., Giraudi, C., and Ruggiero, L., 2016, Tiber delta CO2-CH4 degassing: a possible hybrid, tectonically active Sediment-Hosted Geothermal System near Rome: J. Geophys. Res. Solid Earth, v. 121, doi: 10.1002/2015JB012557.

Craig, H., 1961, Isotopic variations in meteoric waters: Science v. 133, p. 1702-1703.

Dählmann, A., and de Lange, G. J., 2003, Fluid-sediment interactions at Eastern Mediterranean mud volcanoes: a stable isotope study from ODP Leg 160: Earth and Planetary Science Letters, v. 212, p. 377-391.

Etiope, G., 2015, Natural Gas Seepage. The Earth's hydrocarbon degassing: Springer International Publishing Switzerland, ISBN 978-3-319-14601-0 (eBook), DOI 10.1007/978-3-319-14601-0., p. 199.

Etiope, G., and Martinelli, G., 2009, "Pieve Santo Stefano" is not a mud volcano: Comment on "Structural controls on a carbon dioxide-driven mud volcano field in the Northern Apennines" (by Bonini, 2009): Journal of Structural Geology, v. 31, p. 1270-1271.

Gehre, M., and Strauch, G., 2003, High-temperature elemental analysis and pyrolysis techniques for stable isotope analysis: Rapid Commun. Mass Spectrom. , v. 17, p. 1497-1503.

Gibson, J. J., Birks, S. J., and Edwards, T. W. D., 2008, Global prediction of delta(A) and delta(2)Hdelta(18)O evaporation slopes for lakes and soil water accounting for seasonality: Global Biogeochemical Cycles, v. 22.

Gieskes, J. M., Elderfield, H., and Palmer, M. R., 1986, Strontium and Its Isotopic Composition in Interstitial Waters of Marine Carbonate Sediments: Earth and Planetary Science Letters, v. 77, p. 229-235.

Gieskes, J. M., Gamo, T., and Brumsack, H., 1991, Chemical methods for interstitial water analysis aboard Joides Resolution., ODP, Texas A\&M University, tech. note 15, 60 p.:

Gieskes, J. M., and Mahn, C., 2007, Halide systematics in interstitial waters of ocean drilling sediment cores: Applied Geochemistry, v. 22, p. 515-533.

Haese, R. R., Hensen, C., and de Lange, G. J., 2006, Pore water geochemistry of eastern Mediterranean mud volcanoes: Implications for fluid transport and fluid origin: Marine Geology, v. 225, p. 191-208.

Hensen, C., Nuzzo, M., Hornibrook, E., Pinheiro, L. M., Bock, B., Magalhaes, V. H., and Bruckmann, W., 2007, Sources of mud volcano fluids in the Gulf of Cadiz - indications for hydrothermal imprint: Geochimica et Cosmochimica Acta, v. 71, p. 1232-1248.

Hensen, C., et al., 2015, Strike-slip faults mediate the rise of crustal-derived fluids and mud volcanism in the deep sea: Geology, v. 43, p. 339-342.

Holford, S. P., Schofield, N., Jackson, C. A.-L., Magee, C., Green, P. F., and Duddy, I. R., 2013, Impacts of igneous intrusions on source and reservoir potential in prospective sedimentary basins 
along the Western Australian Continental Margin., in Keep, M., and Moss, S. J., eds.: The Sedimentary Basins of Western Australia IV. Proceedings of the Petroleum Exploration Society of Australia Symposium, Perth, WA, 2013.

Istadi, B., Wibowo, H. T., Sunardi, E., Hadi, S., and Sawolo, N., 2012, Mud Volcano and Its Evolution: In tech, v. ISBN 978-953-307-861-8, p. 375-434.

Istadi, B. P., Pramono, G. H., Sumintadireja, P., and Alam, S., 2009, Modeling study of growth and potential geohazard for LUSI mud volcano: East Java, Indonesia: Marine and Petroleum Geology, v. 26, p. 1724-1739.

Ivanov, M. K., Limonov, A. F., and van Weering, T. C. E., 1996, Comparative characteristics of the Black Sea and Mediterranean Ridge mud volcanoes: Marine Geology, v. 132, p. 253-271.

James, R. H., Rudnicki, M. D., and Palmer, M. R., 1999, The alkali element and boron geochemistry of the Escanaba Trough sediment-hosted hydrothermal system: Earth and Planetary Science Letters, v. 171, p. 157-169.

Jamtveit, B., Svensen, H., Podladchikov, Y., and Planke, S., 2004, Hydrothermal vent complexes associated with sill intrusions in sedimentary basins: Geological Society, London, Special Publications, v. 234, p. 233-241.

Karyono, K., Obermann, A., Lupi, M., Masturyono, M., Hadi, S., Syafri, I., Abdurrokhim, A., and Mazzini, A., 2016, Lusi, a clastic dominated geysering system in Indonesia recently explored by surface and subsurface observations: Terra Nova, p. doi: 10.1111/ter.12239.

Martin, J. B., Gieskes, J. M., Torres, M., and Kastner, M., 1993, Bromine and iodine in Peru margin sediments and pore fluids: Implications for fluid origins: Geochimica et Cosmochimica Acta, v. 57, p. 4377-4389.

Mazzini, A., and Etiope, G., 2017, Mud volcanism: An updated review: Earth-Science Reviews, v. 168, p. 81-112.

Mazzini, A., Etiope, G., and Svensen, H., 2012, A new hydrothermal scenario for the 2006 Lusi eruption, Indonesia. Insights from gas geochemistry: Earth and Planetary Science Letters, $\mathrm{v}$. 317, p. 305-318.

Mazzini, A., Hadi, S., Etiope, G., and Inguaggiato, S., 2014, Tectonic Control of Piercement Structures in Central Java, Indonesia.: American Geophysical Union, Fall Meeting 2014, abstract \#OS21B-1138, v. \#OS21B-1138.

Mazzini, A., Nermoen, A., Krotkiewski, M., Podladchikov, Y., Planke, S., and Svensen, H., 2009, Strikeslip faulting as a trigger mechanism for overpressure release through piercement structures. Implications for the Lusi mud volcano, Indonesia: Marine and Petroleum Geology, v. 26, p. 1751-1765.

Mazzini, A., Svensen, H., Akhmanov, G. G., Aloisi, G., Planke, S., Malthe-Sorenssen, A., and Istadi, B., 2007, Triggering and dynamic evolution of the LUSI mud volcano, Indonesia: Earth and Planetary Science Letters, v. 261, p. 375-388.

Mazzini, A., Svensen, H., Etiope, G., Onderdonk, N., and Banks, D., 2011, Fluid origin, gas fluxes and plumbing system in the sediment-hosted Salton Sea Geothermal System (California, USA): Journal of volcanology and geothermal research, v. 205, p. 67-83.

Moscariello, A., Do Couto, D., Mondino, F., Booth, J., Lupi, M., and Mazzini, A., this issue, Genesis and evolution of the Watukosek fault system in the Lusi area (East Java): (this issue) Marine \& Petroleum Geology.

Planke, S., Svensen, H., Hovland, M., Banks, D., and Jamtveit, B., 2003, Mud and fluid migration in active mud volcanoes in Azerbaijan: Geo-Marine Letters, v. 23, p. 258-268.

Richter, F. M., and Depaolo, D. J., 1988, Diagenesis and Sr Isotopic Evolution of Seawater Using Data from Dsdp-590b and Dsdp-575: Earth and Planetary Science Letters, v. 90, p. 382-394.

Samankassou, E., Mazzini, A., Chiaradia, M., and Spezzaferri, S., this volume, The carbonate deposits underneath the geysering Lusi eruption (Java, Indonesia): Marine \& Petroleum Geology. 
Satyana, A. H., 2008, Mud diapirs and mud volcanoes in depressions of Java to Madura: origins, natures, and implications to petroleum system: IPA 32nd Annual Convention Proceedings, v. IPA08-G-139, p. 1-34.

Sawolo, N., Sutriono, E., Istadi, B. P., and Darmoyo, A. B., 2009, The LUSI mud volcano triggering controversy: Was it caused by drilling?: Marine and Petroleum Geology, v. 26, p. 1766-1784.

Scholz, F., Hensen, C., De Lange, G. J., Haeckel, M., Liebetrau, V., Meixner, A., Reitz, A., and Romer, R. L., 2010a, Lithium isotope geochemistry of marine pore waters - Insights from cold seep fluids: Geochimica et Cosmochimica Acta, v. 74, p. 3459-3475.

Scholz, F., Hensen, C., Lu, Z., and Fehn, U., 2010b, Controls on the 129I/I ratio of deep-seated marine interstitial fluids: 'Old' organic versus fissiogenic 129-iodine: Earth and Planetary Science Letters, v. 294, p. 27-36.

Scholz, F., Hensen, C., Reitz, A., Romer, R. L., Liebetrau, V., Meixner, A., Weise, S. M., and Haeckel, M., 2009, Isotopic evidence $(87 \mathrm{Sr} / 86 \mathrm{Sr}$, [delta]7Li) for alteration of the oceanic crust at deep-rooted mud volcanoes in the Gulf of Cadiz, NE Atlantic Ocean: Geochimica et Cosmochimica Acta, v. 73, p. 5444-5459.

Scholz, F., Hensen, C., Schmidt, M., and Geersen, J., 2013, Submarine weathering of silicate minerals and the extent of pore water freshening at active continental margins: Geochimica et Cosmochimica Acta, v. 100, p. 200-216.

Sciarra, A., Mazzini, A., and al, e., this volume, Measurements of 222Rn, 220Rn, $\mathrm{CO} 2$ and $\mathrm{CH} 4$ in soil gas profiles on LUSI site, along the Watukosek fault system (Java, Indonesia): (this issue) Marine \& Petroleum Geology.

Shanks, W. V., Böhlke, J. K., and Seal, R. R., 1995, Stable isotopes in mid-ocean ridge hydrothermal systems: interactions between fluids, minerals, and organisms, in S.E. Humphris, R. A. Z., L.S. Mullineaux, R.E. Thompson ed., Seafloor Hydrothermal Systems: Physical, Chemical, Biological and Geological Interactions, Volume 91, AGU Monograph. American Geophysical Union (1995), pp. , p. 194-221.

Sheppard, S. M. F., and Gilg, H. A., 1996., 1996, Stable isotope geochemistry of clay minerals: Clay Mineralogy, v. 31, p. 1-24.

Simoneit, B. R. T., 1985, Hydrothermal Petroleum - Genesis, Migration, and Deposition in Guaymas Basin, Gulf of California: Canadian Journal of Earth Sciences, v. 22, p. 1919-1929.

Svensen, H., Karlsen, D. A., Sturz, A., Backer-Owe, K., Banks, D., and Planke, S., 2007, Processes controlling water and hydrocarbon composition in seeps from the Salton Sea geothermal system, California, USA: Geology, v. 35, p. 85-88.

Vondamm, K. L., Edmond, J. M., Measures, C. I., and Grant, B., 1985, Chemistry of Submarine Hydrothermal Solutions at Guaymas Basin, Gulf of California: Geochimica et Cosmochimica Acta, v. 49, p. 2221-2237.

Welhan, J. A., and Lupton, J. E., 1987, Light-Hydrocarbon Gases in Guaymas Basin Hydrothermal Fluids - Thermogenic Versus Abiogenic Origin: Aapg Bulletin-American Association of Petroleum Geologists, v. 71, p. 215-223.

You, C.-F., and Gieskes, J. M., 2001, Hydrothermal alteration of hemi-pelagic sediments: experimental evaluation of geochemical processes in shallow subduction zones: Applied Geochemistry, v. 16, p. 1055-1066. 

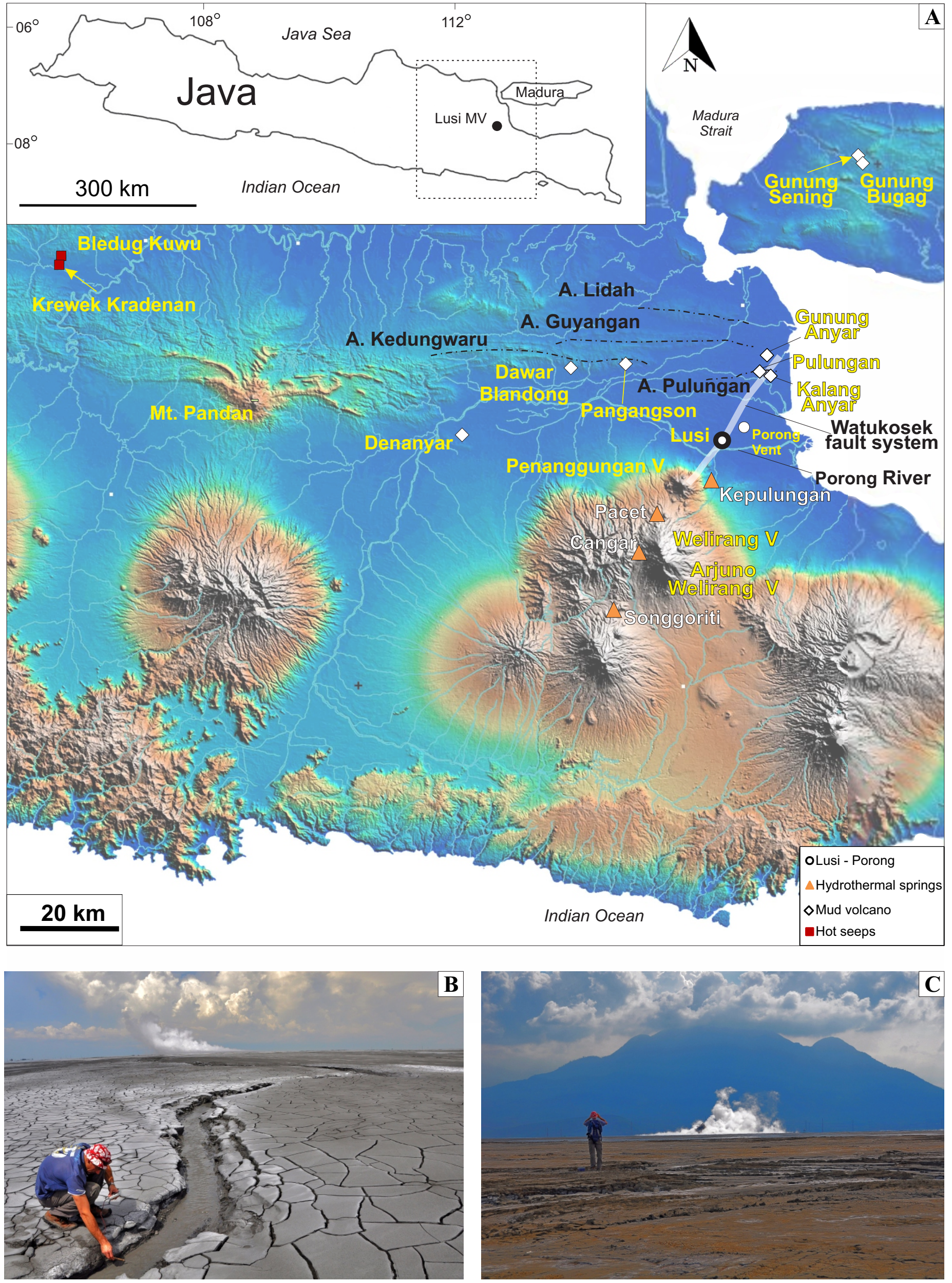


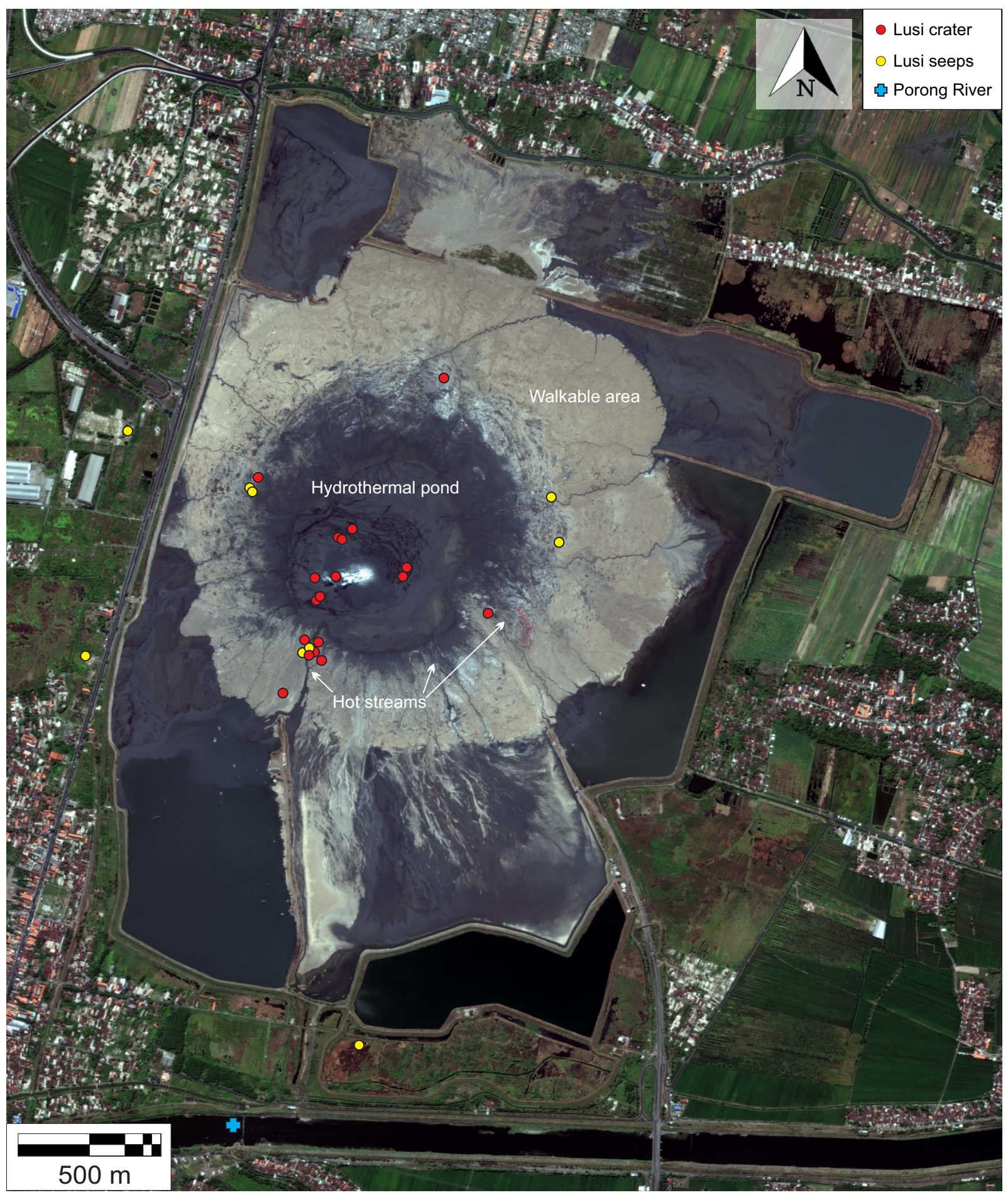




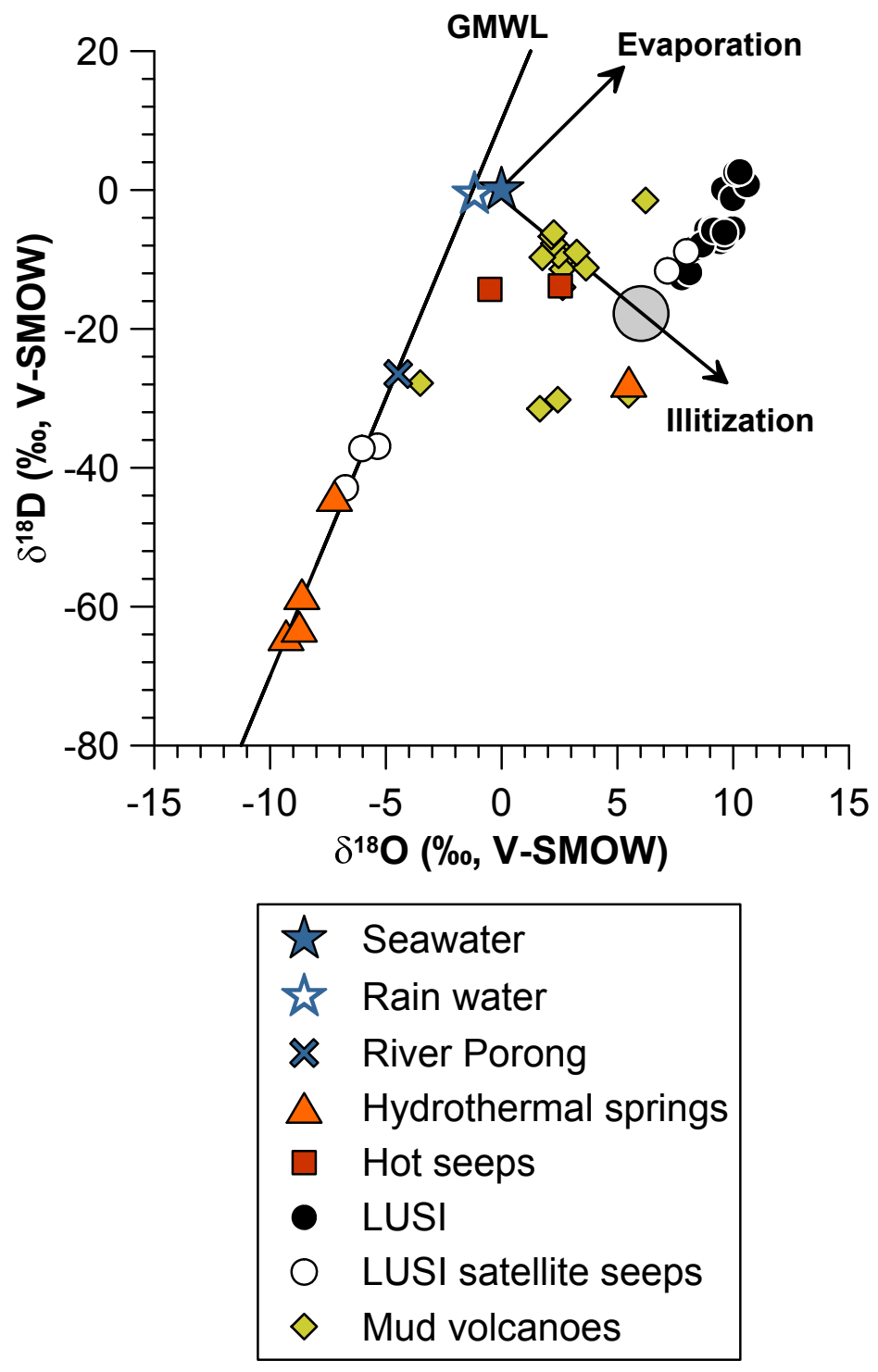




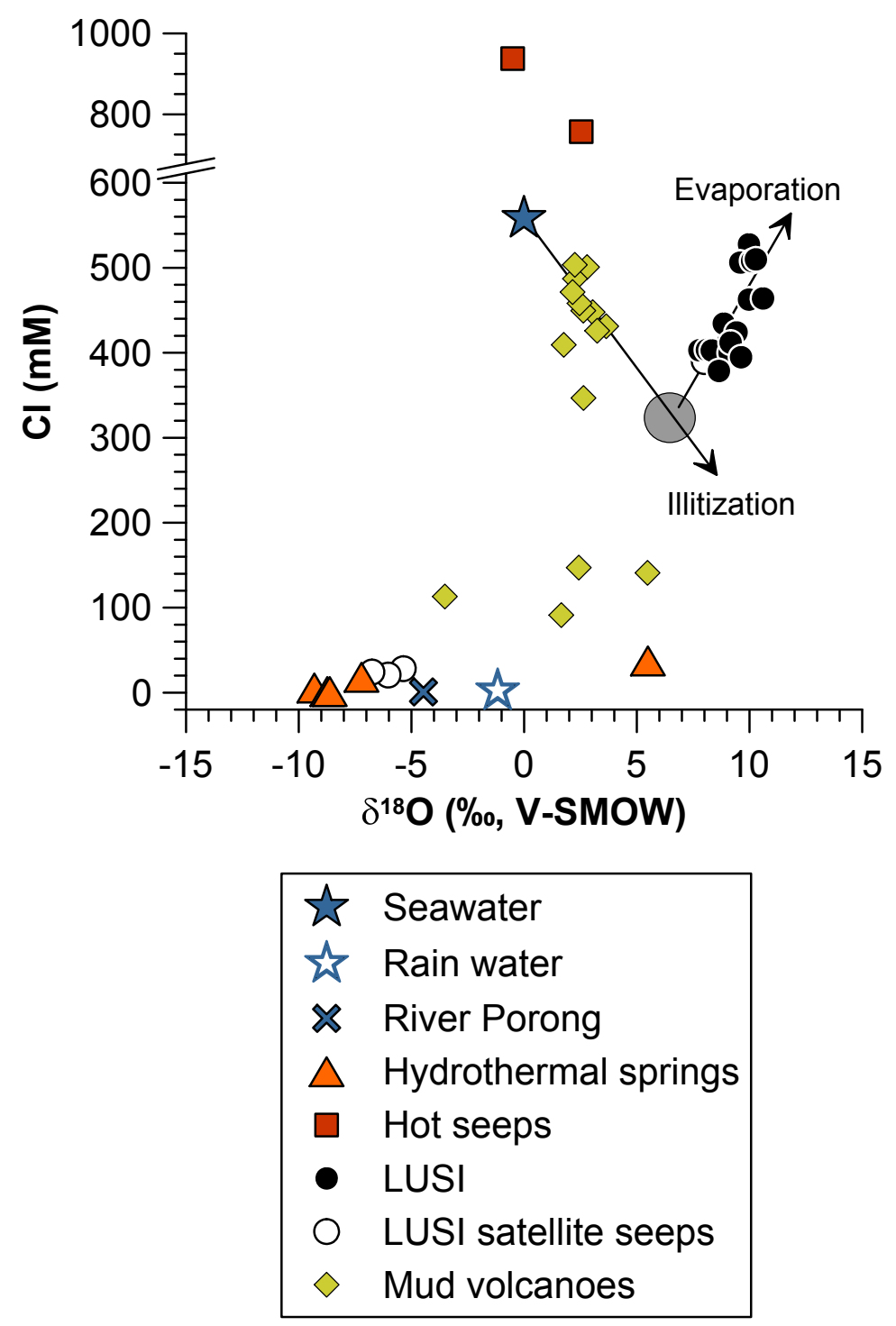




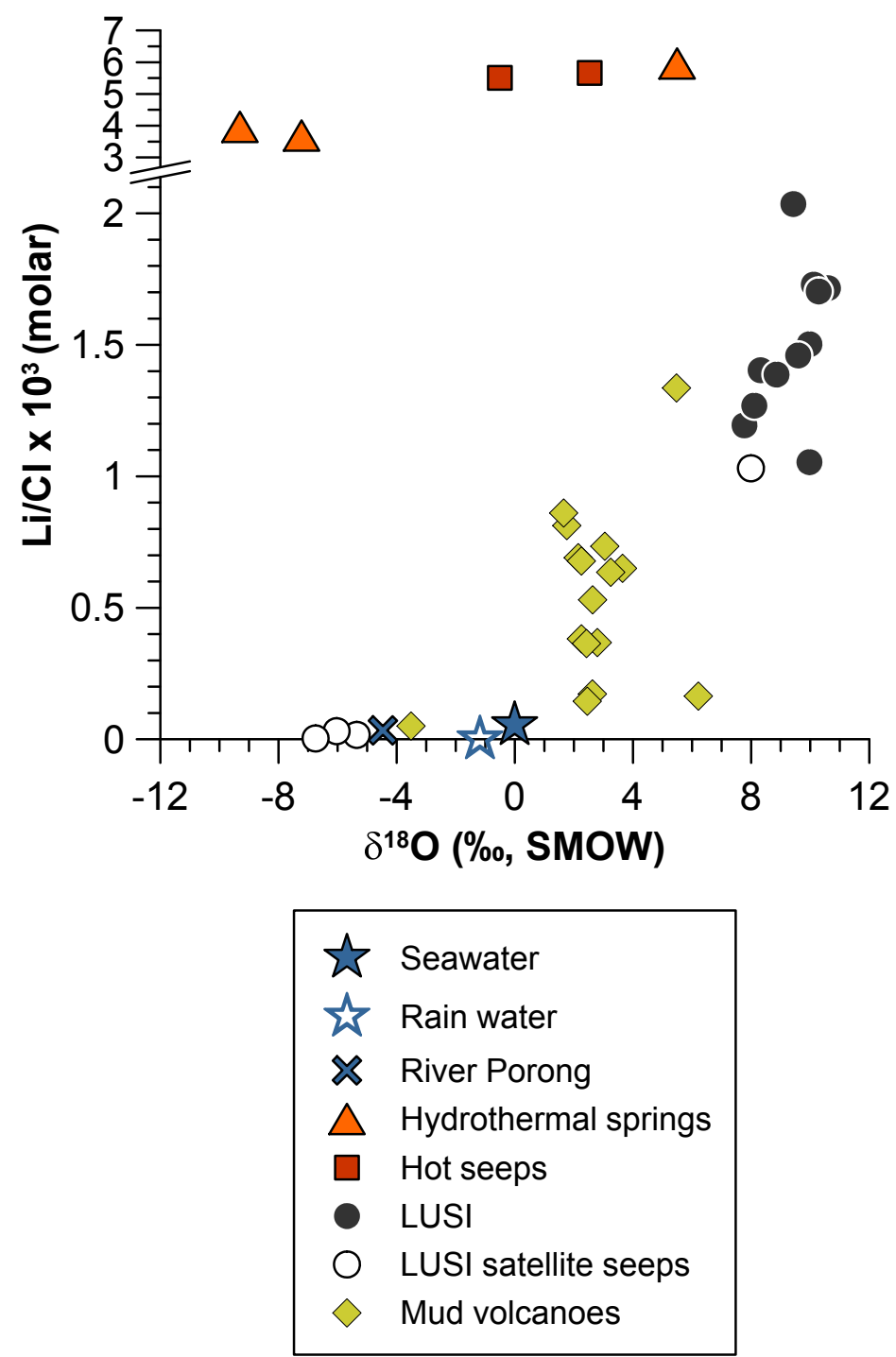


B

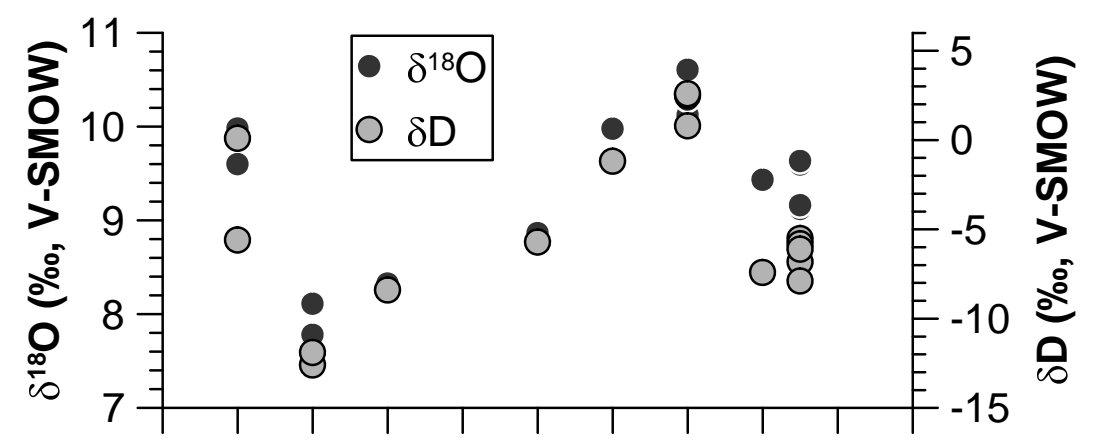

A

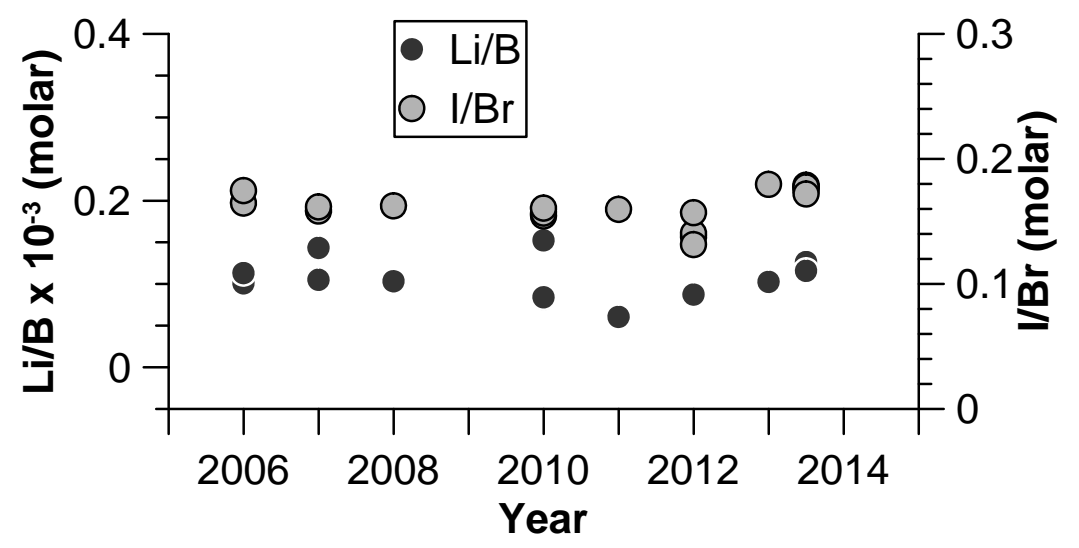




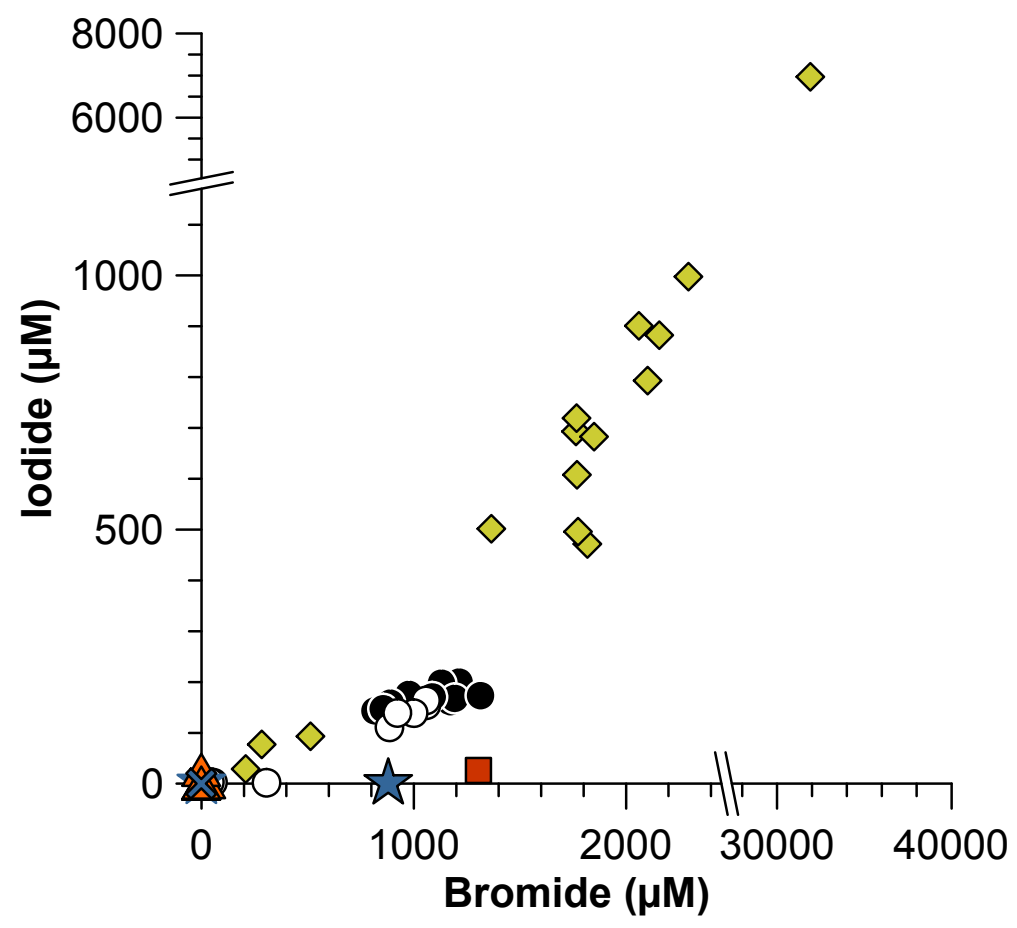
论 Seawater
次 Rain water
× River Porong
$\triangle$ Hydrothermal springs
- Hot seeps
- LUSI
$\bigcirc$ LUSI satellite seeps
$\diamond$ Mud volcanoes 


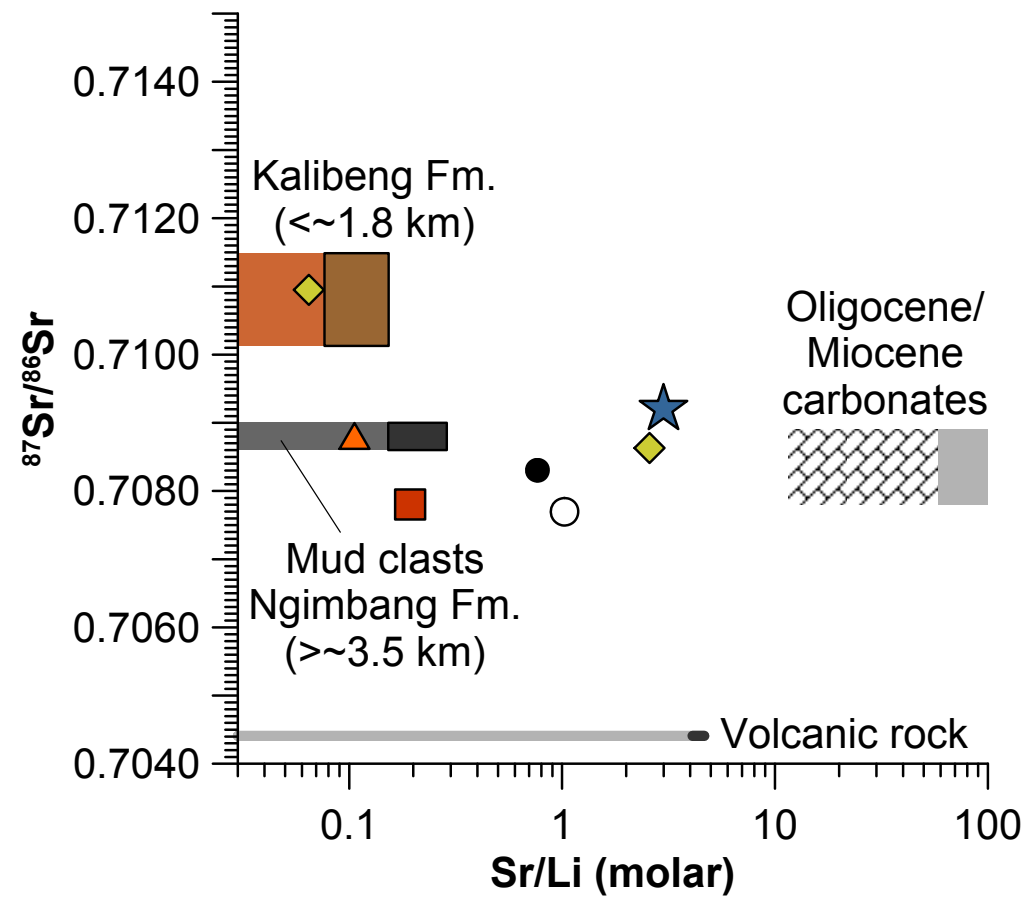

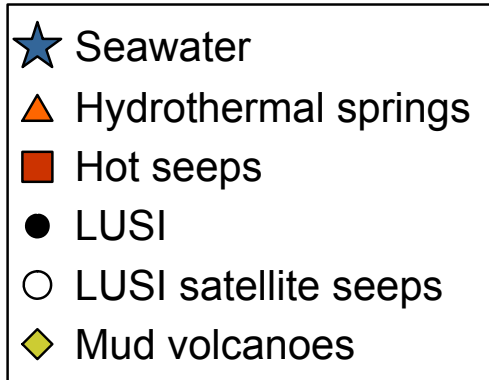




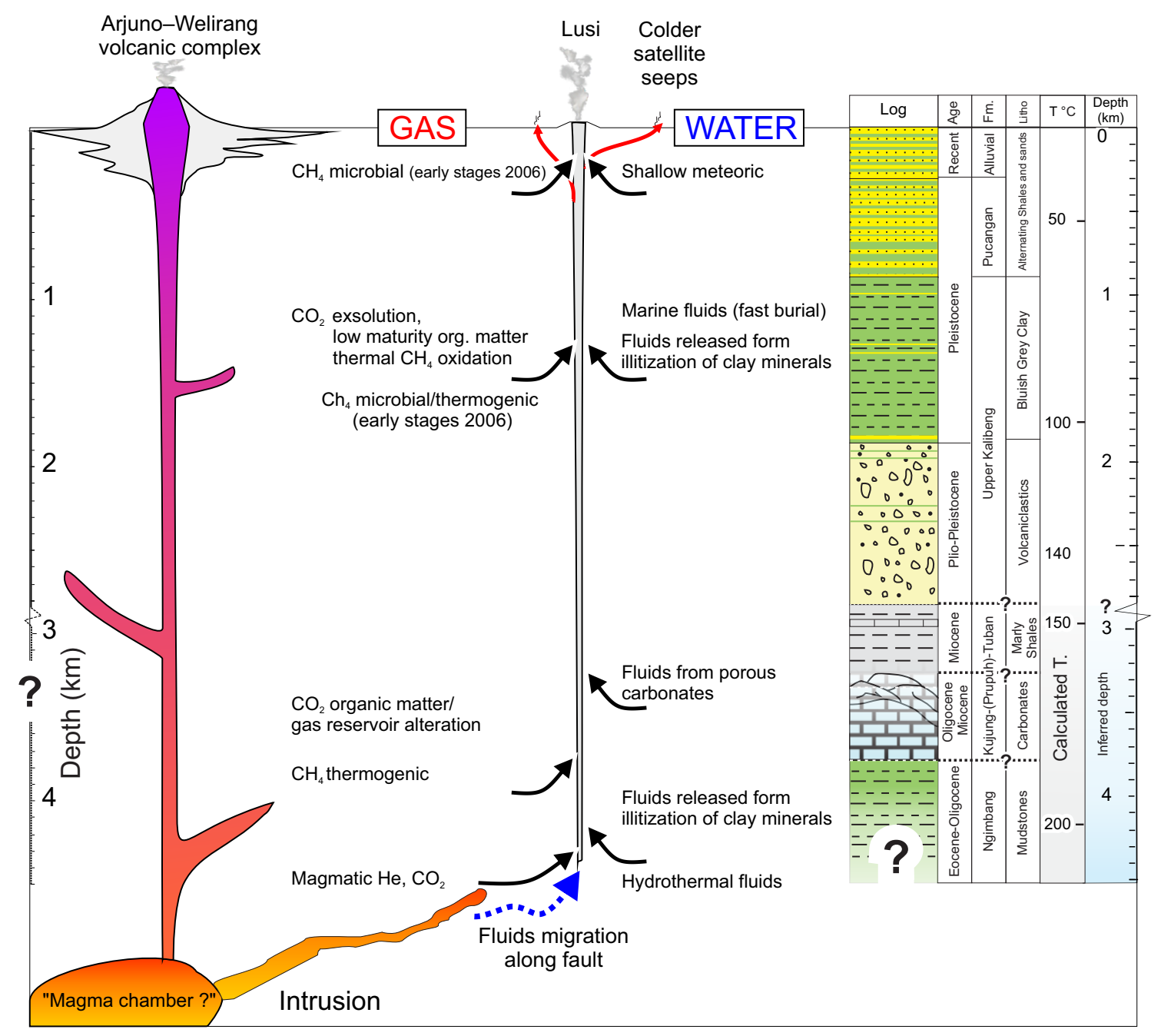




\begin{tabular}{|c|c|c|c|c|c|c|c|c|c|c|c|c|c|c|c|c|c|c|c|c|c|c|c|c|}
\hline $\begin{array}{l}\text { Station } \\
\text { number }\end{array}$ & Year & $\begin{array}{l}\text { Structure / } \\
\text { Locality }\end{array}$ & $\mathrm{T}$ int $\mathrm{C}$ & Text C & pH & B (mM) & $\begin{array}{l}\mathrm{Ca} \\
(\mathrm{mM})\end{array}$ & $\begin{array}{l}\mathrm{Na} \\
(\mathrm{mM})\end{array}$ & $\begin{array}{l}\mathrm{Mg} \\
(\mathrm{mM})\end{array}$ & $\operatorname{Sr}(\mu \mathrm{M})$ & $\mathrm{Si}(\mathrm{mM})$ & $\begin{array}{l}\mathrm{Ba} \\
(\mu \mathrm{M})\end{array}$ & $\mathbf{L i}(\mu \mathrm{M})$ & $\begin{array}{l}\mathrm{K} \\
(\mathbf{m M})\end{array}$ & $\begin{array}{l}\mathrm{Cl} \\
(\mathbf{m M})\end{array}$ & $\begin{array}{l}\text { S04 } \\
(\mathrm{mM})\end{array}$ & $\operatorname{Br}(\mu \mathrm{M})$ & $\mathbf{I}(\mu \mathrm{M})$ & Mn uM & $\begin{array}{l}\delta^{18} \mathbf{O} \\
\text { vsmow }\end{array}$ & $\begin{array}{l}\delta \text { D } \\
\text { vsmow }\end{array}$ & $\begin{array}{l}{ }^{87} \mathrm{Sr} / \\
{ }^{80} \mathrm{Sr}\end{array}$ & $\begin{array}{l}\delta^{13} \mathrm{C} \\
\text { vPDB }\end{array}$ & Comments \\
\hline & & MV along fault zol & & & & & & & & & & & & & & & & & & & & & & \\
\hline JV06-08 & 2006 & Gunung Anyar & 42.9 & 37.2 & 6.48 & 7.29 & 0.07 & 379.35 & 2.80 & 11.92 & 0.58 & 160 & 183.78 & 1.79 & 346.68 & 0.18 & 1365.98 & 501.34 & & 2.64 & -14.00 & 0.7109 & 23.19 & Oil seep on flank of the MV \\
\hline JV06-10 & 2006 & Gunung Anyar & 33.1 & 32.5 & 6.85 & 6.55 & 0.18 & 459.84 & 3.09 & 40.17 & 0.55 & 113 & 328.60 & 2.42 & 447.81 & 0.40 & 1818.67 & 471.42 & & 3.05 & -9.70 & & 13.20 & Seepages on flat area at foot of MV. Small sample of salty water collected. \\
\hline JV06-11 & 2006 & Gunung Anyar & 26.7 & 32.5 & & 1.28 & 3.56 & 116.04 & 5.45 & 58.38 & 0.71 & 556 & 5.63 & 1.12 & 112.99 & 4.19 & 513.54 & 93.22 & & -3.51 & -27.80 & & -8.18 & Sample from water well on edge of crater \\
\hline JV06-17 & 2006 & Pulungan & 29.3 & 33.8 & 7.29 & 5.16 & 0.21 & 508.73 & 4.36 & 28.27 & 0.24 & 729 & 184.23 & 1.89 & 500.81 & 0.28 & 2060.82 & 900.79 & & 2.80 & -9.50 & & 18.55 & $\begin{array}{l}\text { Seepage with salt crusts and microbial colonies at crater. Originally covered by } \\
\text { a house }\end{array}$ \\
\hline JV06-12 & 2006 & Kalang Anyar & 30.6 & 33.6 & 6.80 & 3.57 & 1.65 & 417.08 & 10.89 & 191.98 & 0.15 & 10683 & 77.25 & 3.49 & 449.56 & 0.47 & 1773.90 & 495.80 & & 2.63 & -11.40 & & 10.58 & Small seep with microbial colonies around \\
\hline JV06-13 & 2006 & Kalang Anyar & 31.2 & 33.6 & & 2.38 & 1.91 & 425.74 & 10.64 & 211.72 & 0.16 & 10558 & 66.24 & 2.85 & 458.20 & 0.17 & 1764.09 & 692.92 & & 2.46 & -9.40 & & 10.83 & Small seep with microbial colonies around \\
\hline JV06-14 & 2006 & Kalang Anyar & & & & 55.70 & 18.15 & 4409.55 & 124.68 & 4724.99 & 0.07 & 30696 & 953.30 & 39.03 & 5808.51 & 5.58 & 31912.00 & 6968.31 & & 6.22 & -1.50 & & 7.00 & Poorly active seepage with thick salt crust (strong evaporation) \\
\hline JV06-16 & 2006 & Kalang Anyar & 32.9 & 33.6 & 7.01 & 6.57 & 0.52 & 433.37 & 3.54 & 228.81 & 0.28 & 6539 & 280.13 & 2.04 & 431.12 & 0.48 & 1769.76 & 607.41 & & 3.65 & -11.20 & & 10.50 & Complex of pools \\
\hline JV08-02 & 2008 & Kalang Anyar & 31.0 & 31.1 & & 6.38 & 0.99 & 426.62 & 3.55 & 236.12 & 0.22 & 7306 & 270.31 & 1.91 & 425.83 & 0.45 & 1849.66 & 682.79 & & 3.25 & -9.00 & & 10.30 & Large field of several pools with seepage of water and gas \\
\hline JV08-01A & 2008 & Gunung Anyar & & & & 0.06 & 0.94 & 0.94 & 0.74 & 5.32 & 0.51 & 768 & 0.45 & 0.22 & 2.51 & 0.82 & 0.00 & 1.35 & & & & & & Water well close to crater $\sim 8 \mathrm{~m}$ deep \\
\hline JV08-01 & 2008 & Gunung Anyar & 30.3 & 31.1 & & 5.38 & 1.50 & 417.03 & 2.64 & 549.80 & 0.35 & 12492 & 332.55 & 2.12 & 409.35 & 0.66 & 1767.43 & 718.94 & & 1.77 & -9.70 & & 14.80 & Seepage inside the crater, oily fluids and mud seeping with gas. \\
\hline \multirow[t]{2}{*}{ JV08-04 } & 2008 & Pulungan & & & & 5.52 & 2.24 & 489.75 & 4.81 & 464.55 & 0.24 & 16491 & 186.10 & 2.04 & 486.97 & 0.27 & 2102.31 & 793.08 & & 2.26 & -7.70 & & 17.70 & $\begin{array}{l}\text { Seepage in a room inside the house. The house is sitting on the top of the mud } \\
\text { volcano. }\end{array}$ \\
\hline & & Madura Island MV & & & & & & & & & & & & & & & & & & & & & & \\
\hline JV08-07 & 2008 & Gunung Bulag & 31.1 & 29.5 & & 4.54 & 0.33 & 119.31 & 0.62 & 65.27 & 0.22 & 13266 & 78.55 & 0.25 & 91.29 & 0.24 & 208.37 & 28.52 & & 1.66 & -31.50 & & 7.50 & $\begin{array}{l}\text { Lake iniside the MV crater (8 } \mathrm{m} \text { in diameter) where seepage occurs at two } \\
\text { localities }\end{array}$ \\
\hline \multirow[t]{2}{*}{ JV08-06 } & 2008 & Gunung Sening & & & & 6.36 & 0.26 & 188.93 & 0.73 & 52.01 & 0.11 & 12074 & 53.56 & 0.25 & 147.08 & 1.14 & 284.34 & 76.90 & & 2.43 & -30.20 & & 15.80 & $\begin{array}{l}\text { Small sized pool ( } 1.5 \mathrm{~m} \text { in diameter) ab. } 100 \mathrm{~m} \text { away from the foot of the tall } \\
\text { gryphon }\end{array}$ \\
\hline & & MV along anticlin & & & & & & & & & & & & & & & & & & & & & & \\
\hline JV08-09 & 2008 & Pangangson & 33.5 & 37.3 & & 4.99 & 2.47 & 461.56 & 5.73 & 839.84 & 0.27 & 45286 & 325.35 & 2.28 & 471.41 & 0.50 & 2156.60 & 882.15 & & 2.15 & -6.70 & 0.7086 & 14.00 & $\begin{array}{l}\text { Field of numerous pools inside the crater, sampled } 30 \mathrm{~cm} \text { wide pool, mainly } \\
\text { water, gas }\end{array}$ \\
\hline \multirow[t]{2}{*}{ JV08-10 } & 2008 & Pangangson & 34.6 & 38.5 & & 5.85 & 1.56 & 492.10 & 5.82 & 978.30 & 0.20 & 41174 & 341.10 & 2.78 & 503.49 & 0.73 & 2294.17 & 997.37 & & 2.25 & -6.20 & & 14.40 & System of terraced pools on east flank of the MV crater \\
\hline & & Hot seeps & & & & & & & & & & & & & & & & & & & & & & \\
\hline JV08-11 & 2008 & Bledug Kuwu & 31.1 & 29.4 & & 10.18 & 13.94 & 839.53 & 5.82 & 999.11 & 0.11 & 11147 & 5162.81 & 14.44 & 937.79 & 10.23 & 1692.70 & & & -0.50 & -14.30 & 0.7078 & & $1 \mathrm{~m}$ sized seepage inside crater, bursts every $1 \mathrm{~min}$ \\
\hline \multirow[t]{2}{*}{ JV08-12 } & 2008 & Krewek & & & & 14.91 & 1.79 & 691.91 & 5.33 & 746.42 & 1.88 & 16427 & 4283.13 & 10.36 & 756.89 & 0.00 & 1305.49 & 25.96 & & 2.54 & -13.80 & & 6.70 & Seeps inside crater covered by travertine \\
\hline & & Hydrothermal sprin & & & & & & & & & & & & & & & & & & & & & & \\
\hline JV07-10 & 2007 & Pacet & 48.2 & 27.0 & 6.34 & 0.39 & 0.26 & 3.89 & 4.18 & 0.56 & 1.64 & 68 & 21.77 & 1.06 & 5.50 & 0.31 & 0.00 & 0.57 & & -9.30 & -64.10 & & & Hot spring at Pacet locality \\
\hline JV07-11 & 2007 & Cangar & 54.0 & & 6.57 & 0.23 & 1.49 & 0.00 & 3.26 & 4.80 & 1.84 & 1471 & 0.00 & 0.58 & 1.24 & 0.96 & 0.00 & 0.21 & & -8.73 & -62.90 & & & Hot spring locality Cangar, water from rock outcrop \\
\hline JV11-10 & 2011 & Pacet & 47.2 & & & 0.48 & 2.03 & 5.07 & 4.17 & 7.90 & 2.48 & 4156 & 20.06 & 0.83 & 5.21 & 2.33 & 0.00 & 0.40 & & & & & & $\begin{array}{l}\text { Pacet locality. Source of hydrothermal water inside the river, locality close to } \\
\text { that sampled also at JV07-10 }\end{array}$ \\
\hline JV11-09 & 2011 & Cangar & 48.5 & & & 0.31 & 1.64 & 0.00 & 3.06 & 5.32 & 1.78 & 3040 & 0.00 & 0.40 & 1.10 & 1.37 & 0.00 & 0.00 & & & & & & Cangar locality. Source of hydrothermal water, locality sampled also at JV07-11 \\
\hline JV11-09A & 2011 & Cangar & & & & 0.23 & 1.55 & 0.00 & 3.07 & 5.44 & 1.79 & 23955 & 0.00 & 0.47 & 1.30 & 0.86 & 0.00 & 0.00 & & -8.62 & -58.21 & & & Cangar locality. Source of hydrothermal water, locality sampled also at JV07-11 \\
\hline JV11-07 & 2011 & Songgoriti & 43.0 & 22.5 & & 3.89 & 4.36 & 24.94 & 4.93 & 25.52 & 2.87 & 7016 & 198.85 & 0.97 & 20.84 & 0.00 & 22.69 & 2.79 & & & & & & $\begin{array}{l}\text { Songgoriti locality. Source of hydrothermal water vigorous seepage of gas, } \\
\text { water }\end{array}$ \\
\hline JV11-08 & 2011 & Songgoriti & 45.9 & & & 4.41 & 2.28 & 30.18 & 5.38 & 23.58 & 2.96 & 23094 & 221.94 & 1.05 & 37.26 & 0.49 & 0.00 & 27.25 & & 5.50 & -27.60 & 0.7088 & & $\begin{array}{l}\text { Songgoritit locality. Source of hydrothermal water vigorous seepage of gas, } \\
\text { water. Close to JV11-07 }\end{array}$ \\
\hline JV07-12 & 2007 & $\begin{array}{l}\text { Fresh spring @ } \\
\text { Cangar }\end{array}$ & 23.5 & 20.0 & 8.51 & 0.08 & 0.97 & 0.00 & 1.54 & 2.94 & 1.27 & 439 & 0.00 & 0.24 & 0.76 & 0.37 & 0.00 & 0.20 & & -8.41 & -55.10 & & & Fresh water spring near Cangar locality \\
\hline WLR-1 & 2013 & $\begin{array}{l}\text { Fresh water } \\
\text { spring Welirang } \\
\text { Fresh water }\end{array}$ & & & & 0.00 & 0.25 & 0.00 & 0.07 & 0.55 & 0.80 & 42 & & 0.05 & 575.97 & 181.04 & 10.36 & 0.00 & 0.00 & & & & & Welirang volcano fresh springs \\
\hline WLR-2 & 2013 & $\begin{array}{l}\text { Frresn weler } \\
\text { spring Welirang }\end{array}$ & & & & 0.00 & 0.26 & 0.10 & 0.07 & 0.55 & 0.80 & 43 & & 0.05 & 51.39 & 112.13 & 0.58 & 0.00 & & & & & & Welirang volcano fresh springs \\
\hline
\end{tabular}




\begin{tabular}{|c|c|c|c|c|c|c|c|c|c|c|c|c|c|c|c|c|c|c|c|c|c|}
\hline $\begin{array}{l}\text { Station } \\
\text { number }\end{array}$ & $\begin{array}{c}\text { Al } \\
\text { mg/g }\end{array}$ & $\begin{array}{c}\text { Ba } \\
\mathrm{mg} / \mathrm{g}\end{array}$ & $\begin{array}{c}\text { Ca } \\
\mathrm{mg} / \mathrm{g}\end{array}$ & $\begin{array}{c}\mathrm{Cr} \\
\mu \mathrm{g} / \mathrm{g}\end{array}$ & $\begin{array}{c}\mathrm{Cu} \\
\mu \mathrm{g} / \mathrm{g}\end{array}$ & $\begin{array}{c}\mathrm{Fe} \\
\mathrm{mg} / \mathrm{g}\end{array}$ & $\begin{array}{c}\mathrm{K} \\
\mathrm{mg} / \mathrm{g}\end{array}$ & $\begin{array}{c}\mathrm{Li} \\
\mathrm{mg} / \mathrm{g}\end{array}$ & $\begin{array}{c}\mathrm{Mg} \\
\mathrm{mg} / \mathrm{g}\end{array}$ & $\begin{array}{c}\text { Mn } \\
\text { mg/g }\end{array}$ & $\begin{array}{c}\text { Mo } \\
\mu \mathrm{g} / \mathrm{g}\end{array}$ & $\begin{array}{c}\mathrm{Na} \\
\mathrm{mg} / \mathrm{g}\end{array}$ & $\begin{array}{c}\mathrm{Ni} \\
\mu \mathrm{g} / \mathrm{g}\end{array}$ & $\begin{array}{c}\mathrm{Sr} \\
\mathrm{mg} / \mathrm{g}\end{array}$ & $\begin{array}{c}\text { Th } \\
\mu \mathrm{g} / \mathrm{g}\end{array}$ & $\begin{array}{c}\mathrm{Ti} \\
\mathrm{mg} / \mathrm{g}\end{array}$ & $\begin{array}{c}\mathrm{U} \\
\mu \mathrm{g} / \mathrm{g}\end{array}$ & $\begin{array}{c}\mathrm{V} \\
\mu \mathrm{g} / \mathrm{g}\end{array}$ & $\begin{array}{c}\mathrm{Zn} \\
\mu \mathrm{g} / \mathrm{g}\end{array}$ & $\begin{array}{l}{ }^{87} \mathrm{Sr} /{ }^{86} \mathrm{Sr} \mathbf{R b}- \\
\text { corrected }\end{array}$ & Comments \\
\hline BSP1- 3640 & 105.75 & 0.42 & 5.76 & 72.61 & 25.48 & 49.24 & 14.98 & 0.0869 & 11.31 & 1.05 & 0.92 & 6.68 & 28.15 & 0.10 & 12.48 & 4.72 & 2.48 & 132.75 & 96.89 & 0.710129 & $\begin{array}{l}\text { Kalibeng Fm. shale sample from side well core of } \\
\text { BJP1 well at } 3640 \text { feet }\end{array}$ \\
\hline BSP1- 4800 & 90.50 & 1.22 & 5.48 & 72.38 & 28.77 & 42.52 & 14.25 & 0.1014 & 9.26 & 1.23 & 0.59 & 5.07 & 23.96 & 0.10 & 12.33 & 4.85 & 2.62 & 112.19 & 92.85 & $0.710 s$ & $\begin{array}{l}\text { Kalibeng Fm. shale sample from side well core of } \\
\text { BJP1 well at } 4800 \text { feet }\end{array}$ \\
\hline BJP1- 5200 & 95.49 & 5.18 & 7.84 & 74.85 & 42.21 & 51.65 & 13.72 & 0.0765 & 9.59 & 1.89 & 0.73 & 4.75 & 31.48 & 0.15 & 13.07 & 5.03 & 2.82 & 120.22 & 101.26 & 0.711487 & $\begin{array}{l}\text { Kalibeng Fm. shale sample from side well core of } \\
\text { BJP1 well at } 5200 \text { feet }\end{array}$ \\
\hline JV II- 18A & 106.55 & 0.85 & 65.87 & 5.05 & 49.82 & 54.25 & 18.41 & 0.0107 & 18.59 & 1.24 & 1.26 & 24.64 & 6.15 & 0.55 & 5.29 & 4.79 & 1.46 & 213.39 & 65.87 & 0.704407 & $\begin{array}{l}\text { magmatic flow (sampled from volcanic complex } \\
\text { neighbouring to Lusi) }\end{array}$ \\
\hline JV II- 18B & 104.69 & 0.82 & 65.11 & 6.26 & 50.84 & 57.96 & 17.97 & 0.0091 & 16.64 & 1.27 & 0.83 & 22.95 & 6.54 & 0.53 & 5.05 & 5.12 & 1.16 & 215.35 & 66.76 & 0.704412 & $\begin{array}{l}\text { Bottom contact of lava flow with lahar rocks (sampled } \\
\text { from volcanic complex neighbouring to Lusi) }\end{array}$ \\
\hline JV II- DiA & 105.05 & 0.15 & 5.50 & 62.87 & 66.97 & 51.10 & 15.23 & 0.0692 & 13.25 & 1.04 & 1.14 & 7.96 & 28.56 & 0.13 & 11.31 & 4.70 & 2.20 & 134.55 & 144.32 & 0.708862 & $\begin{array}{l}\text { Black shale clasts from mud breccia collected at Lusi } \\
\text { crater site }\end{array}$ \\
\hline JV II- DiA & 107.14 & 0.15 & 5.59 & 63.50 & 68.01 & 51.91 & 15.53 & 0.0709 & 13.54 & 1.07 & 1.26 & 8.12 & 28.72 & 0.14 & 11.41 & 4.79 & 2.20 & 137.04 & 149.70 & & $\begin{array}{l}\text { Black shale clasts from mud breccia collected at Lusi } \\
\text { crater site }\end{array}$ \\
\hline
\end{tabular}

Table 2: molecular and ${ }^{87} \mathrm{Sr} /{ }^{86} \mathrm{Sr}$ isotopic composition of selected rock samples. 